\title{
Estimation of Dose from Potential Radionuclide Emissions from the Sample Preparation Laboratory at the Materials and Fuels Complex
}

\author{
A Jeffrey Sondrup \\ September 2018
}

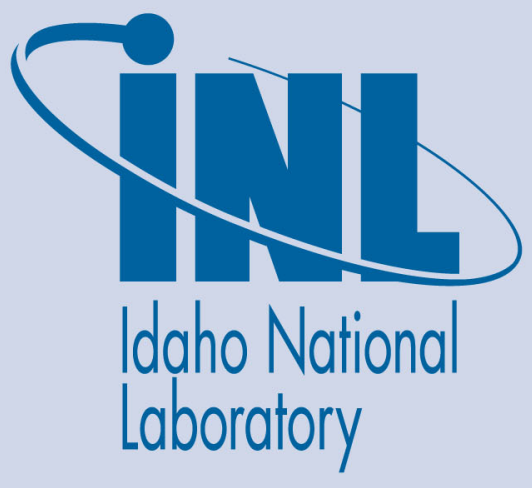

The INL is a U.S. Department of Energy National Laboratory operated by Battelle Energy Alliance 


\title{
Estimation of Dose from Potential Radionuclide Emissions from the Sample Preparation Laboratory at the Materials and Fuels Complex
}

\author{
A Jeffrey Sondrup
}

September 2018

Idaho National Laboratory Idaho Falls, Idaho 83415

http://www.inl.gov

Prepared for the

U.S. Department of Energy

Under DOE Idaho Operations Office

Contract DE-AC07-05ID14517 
Rev. 08

Estimation of dose from potential radionuclide emissions from the Sample Preparation

Title: $\quad$ Laboratory at the Materials and Fuels Complex

$\begin{array}{lllll}\text { ECAR No.: } 4239 & \text { Rev. No.: } & 0 & \text { Project No.: } & \text { N/A }\end{array}$

\begin{tabular}{|c|c|c|}
\hline $\begin{array}{l}\text { 1. Does this ECAR involve } \\
\text { a Safety SSC? }\end{array}$ & N/A & Professional Engineer's Stamp \\
\hline $\begin{array}{l}\text { Safety SSC } \\
\text { 2. Determination Document } \\
\text { ID }\end{array}$ & $\mathrm{N} / \mathrm{A}$ & PE Stamp Not Required per LWP-10010. \\
\hline 3. Engineering Job (EJ) No. & N/A & \\
\hline 4. SSC ID & N/A & \\
\hline 5. Building & $\begin{array}{c}\text { Sample Preparation } \\
\text { Laboratory }\end{array}$ & \\
\hline 6. Site Area & $\begin{array}{l}\text { Materials and Fuels } \\
\text { Complex }\end{array}$ & \\
\hline
\end{tabular}

7. Objective/Purpose:

The Sample Preparation Laboratory (SPL) at the Materials and Fuels Complex will perform sample preparation, examination, and mechanical-property testing of highly irradiated materials. The purpose of this report is to document calculation of the estimated dose at public receptor locations from potential radionuclide releases to the atmosphere from SPL.

Atmospheric dispersion and dose calculations were performed with the computer model CAP88PC Version 4 in accordance with the requirements of Code of Federal Regulations (CFR), Title 40, "Protection of the Environment," Part 61, "National Emission Standards for Hazardous Air Pollutants (NESHAPs)," Subpart H, "National Emission Standards for Emissions of Radionuclides Other than Radon from Department of Energy Facilities" (40 CFR 61, Subpart H 2010). Emission potentials were calculated based on the methodology in 40 CFR Part 61, Appendix D and additional guidance/approval by EPA Region 10 [see letter from Donald Dossett (EPA Region 10) to Tim Safford (DOE-ID), Oct 19, 2017 (CCN 241475)] for solid materials that undergo heating. Estimates of total effective dose are based on low-level chronic exposure.

8. If revision, please state the reason and list sections and/or pages being affected:

NA.

9. Conclusions/Recommendations

The potential maximum dose to a member of the public was calculated to be $0.02 \mathrm{mrem} / \mathrm{year}$ based on an estimated $16 \mathrm{~g}$ of the $30 \mathrm{~kg}$ source term $(0.053 \%)$ being exposed to very high temperatures associated with electrical-discharge machining (EDM) and the remaining material heated to $100^{\circ} \mathrm{C}$. Calculations show the maximum dose could be as high as $0.05 \mathrm{mrem} / \mathrm{year}$ if the remaining material were heated to $1400^{\circ} \mathrm{C}$ (i.e., the melting point of stainless steel).

The potential maximum dose to a public receptor from emissions at SPL is not expected to exceed $0.1 \mathrm{mrem} /$ year (1\% of the standard) so long as the material impacted by EDM does not exceed 
TEM-10200-1

Rev. 08

Estimation of dose from potential radionuclide emissions from the Sample Preparation Title: $\quad$ Laboratory at the Materials and Fuels Complex

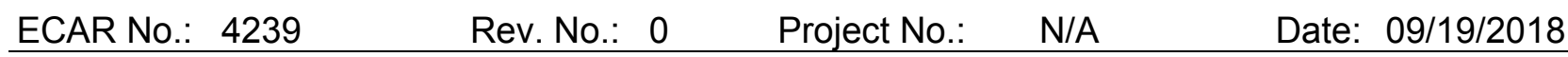

$56 \mathrm{~g}$ (3.5 times the expected mass of $16 \mathrm{~g}$ and less than $0.2 \%$ of the total source term), and the remaining material is not heated to temperatures greater than $1400^{\circ} \mathrm{C}$.

It should be noted that credit for HEPA filtration does not impact the dose results because the dose is dominated by radionuclides that have exceeded their boiling point; thus, no credit for HEPA filtration may be applied to the emission factor. 
Rev. 08

$\begin{array}{ll}\text { Estimation of dose from potential radionuclide em } \\ \text { Title: } & \text { Laboratory at the Materials and Fuels Complex }\end{array}$

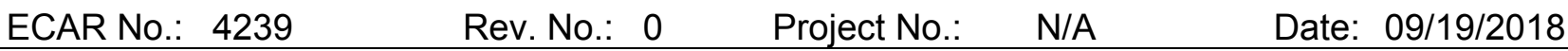

\section{CONTENTS}

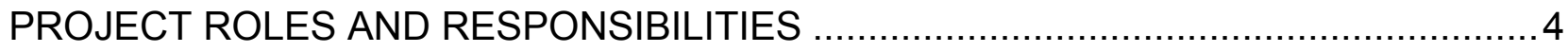

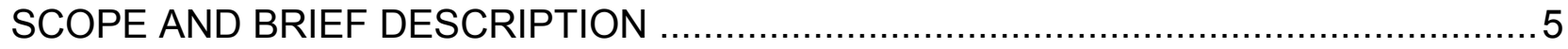

DESIGN OR TECHNICAL PARAMETER INPUT AND SOURCES …........................ 5

Other data sources and references are provided in the Discussion/Analysis section........5

RESULTS OF LITERATURE SEARCHES AND OTHER BACKGROUND DATA .............5

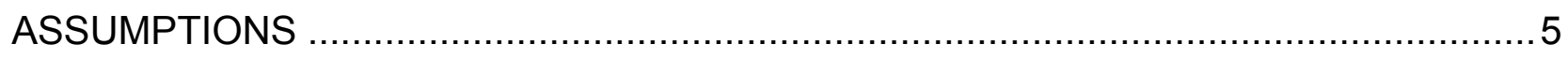

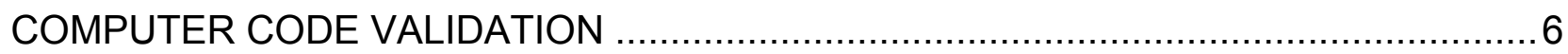

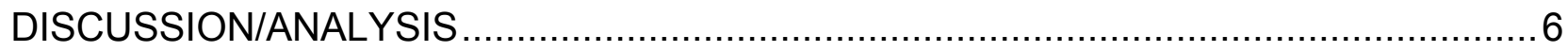

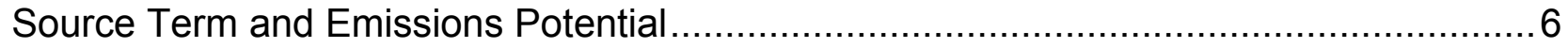

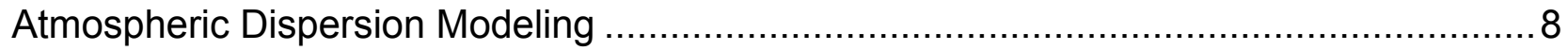

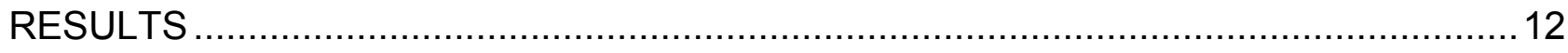

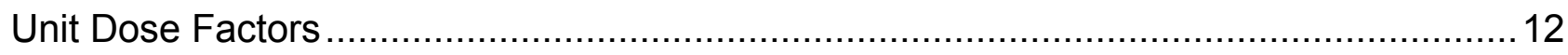

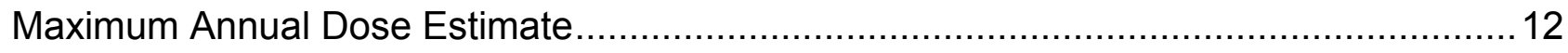

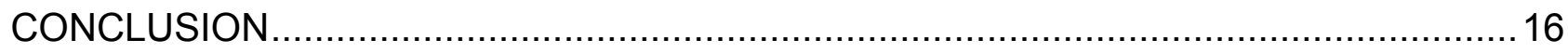

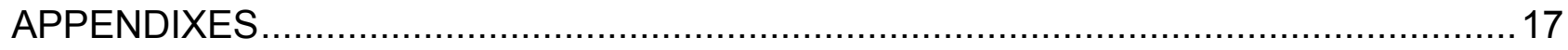

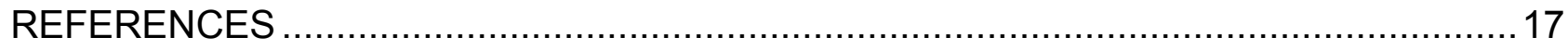

APPENDIXES

Appendix A - Emission Factors

Appendix B - CAP88-PC Windfile (EBRL6-15.WND)

Appendix C - Perl Scripts and Input Files for Pre- and Post-Processing CAP88-PC Input/Output 
Rev. 08

Estimation of dose from potential radionuclide emissions from the Sample Preparation

Title: $\quad$ Laboratory at the Materials and Fuels Complex

$\begin{array}{lllll}\text { ECAR No.: } 4239 & \text { Rev. No.: } 0 & \text { Project No.: } & \text { N/A } & \text { Date: 09/19/2018 }\end{array}$

\section{PROJECT ROLES AND RESPONSIBILITIES}

\begin{tabular}{l|l|l|l}
\multicolumn{1}{c|}{ Project Role } & \multicolumn{1}{|c|}{ Name (Typed) } & Organization & Pages covered (if applicable) \\
\hline Performer & A. Jeffrey Sondrup & B360 \\
Checker & Tim A. Solle & H510 & \\
Independent Reviewer & Mark A. Verdoorn & H530 & N/A \\
CUl Reviewer & N/A & B360 \\
Manager & Chris T. Wright & J211 \\
Requestore & Bill Landman & N/A \\
Nuclear Safetye & N/A & B360 \\
Document Owner & A. Jeffrey Sondrup & \\
Responsibilities: & &
\end{tabular}
a. Confirmation of completeness, mathematical accuracy, and correctness of data and appropriateness of assumptions.
b. Concurrence of method or approach. See definition, LWP-10106.
c. Concurrence with the document's markings in accordance with LWP-11202.
d. Concurrence of procedure compliance. Concurrence with method/approach and conclusion.
e. Concurrence with the document's assumptions and input information. See definition of Acceptance, LWP-10200. 
Rev. 08

Estimation of dose from potential radionuclide emissions from the Sample Preparation

Title: $\quad$ Laboratory at the Materials and Fuels Complex

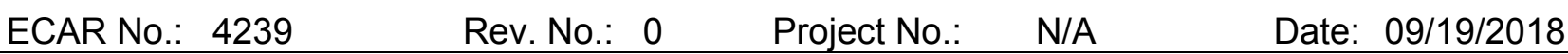

\section{SCOPE AND BRIEF DESCRIPTION}

The Sample Preparation Laboratory (SPL) at the Materials and Fuels Complex will perform sample preparation, examination and mechanical property testing of highly irradiated materials. Specifically, SPL provides:

1. Receipt and preparation of micro- and nano-scale examination and mechanical-propertiestesting samples that involve sizing, grinding, and polishing activities (beta-gamma materials only)

2. Micro- and nano-scale examination of prepared samples (beta-gamma and some alpha materials that would have been prepared elsewhere) in instruments like the scanning electron microscope, a focused ion beam, an X-ray photoelectron spectroscopy

3. Mechanical-properties testing, including tensile testing, high-temperature fatigue testing, and Charpy V-notch testing.

The purpose of this report is to document calculation of the estimated dose at public receptor locations from potential radionuclide releases to the atmosphere from SPL. Atmospheric dispersion calculations were performed in accordance with the requirements of Code of Federal Regulations (CFR), Title 40, "Protection of the Environment," Part 61, "National Emission Standards for Hazardous Air Pollutants (NESHAPs)," Subpart H, "National Emission Standards for Emissions of Radionuclides Other than Radon from Department of Energy Facilities" (40 CFR 61, Subpart H 2010). Emission potentials were calculated based on the methodology in 40 CFR Part 61, Appendix D and additional guidance/approval by EPA Region 10 [see letter from Donald Dossett (EPA Region 10) to Tim Safford (DOE-ID), Oct 19, 2017 (CCN 241475)] for solid materials that undergo heating.

\section{DESIGN OR TECHNICAL PARAMETER INPUT AND SOURCES}

The following are sources for the primary data used in the assessment:

1. The radionuclide source term was taken from ECAR-4023, "Evaluation of the Inhalation Dose Consequences for the Sample Preparation Laboratory" (2018).

2. Melting points and boiling points of the radionuclides were taken from the CRC Handbook of Chemistry and Physics http://hbcponline.com/faces/contents/InteractiveTable.xhtml?tableld=15.

3. Meteorological data from the EBR MESONET station were provided by the Idaho Falls National Ocean Atmospheric Administration (NOAA) Air Resources Laboratory.

Other data sources and references are provided in the Discussion/Analysis section.

\section{RESULTS OF LITERATURE SEARCHES AND OTHER BACKGROUND DATA}

See Discussion/Analysis Section and References Section.

\section{ASSUMPTIONS}

See Discussion/Analysis Section. 
Rev. 08

Estimation of dose from potential radionuclide emissions from the Sample Preparation

Title: $\quad$ Laboratory at the Materials and Fuels Complex

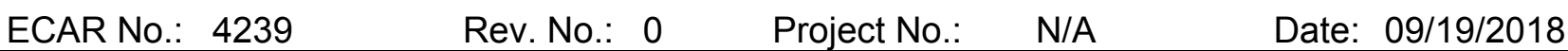

\section{COMPUTER CODE VALIDATION}

All computer code modeling and calculations were performed on a Dell Optiplex 7020 computer (Intel Core i7-4790 CPU @ 3.60 GHz, property tag 604112) running Microsoft Windows 7 Enterprise, Service Pack 1. Atmospheric transport modeling of radionuclide emissions was performed using the CAP88-PC Version 4 (EPA 2013a) computer model. CAP88-PC is a set of computer programs, databases, and associated utility programs for estimation of dose and risk from radionuclide emissions to the air. CAP88-PC is both a mature and the EPA-recommended model for demonstration of compliance with the applicable performance objective (40 CFR 61, Subpart H). Testing and validation of CAP88-PC is performed by EPA and documented in EPA (2013b). Verification of proper installation and operation of CAP88-PC is performed annually at INL by simulating the example problem (Modtest) provided in the CAP88-PC download zip file. Additional information about CAP88-PC can be found at http://www.epa.gov/radiation/assessment/CAP88/aboutcap88.html.

Microsoft Excel 2013 (15.0.5041.1000) MSO (15.0.5031.1000) 32 bit, part of Microsoft Office Professional Plus 2013, was used for supporting calculations and creating graphs of results. Cell formulas were checked for accuracy, and a sample of the calculations was checked by hand. All formula cells have been locked for editing and password protected.

All electronic files, including computer code input, output, and spreadsheet files are contained in a zip file that can be accessed by selecting "Additional Information" (select Native File) in the INL Electronic Document Management System.

\section{DISCUSSION/ANALYSIS}

\section{Source Term and Emissions Potential}

ECAR-4023 identifies the SPL source term, or annual possession quantity, as radionuclide activities in $30 \mathrm{~kg}$ of Type 316 stainless steel (SS) irradiated to a fluence of $5 \times 10^{21}$ neutrons $/ \mathrm{cm}^{2}$ with a decay time of 30 days. This source term has been identified as a reasonable amount of mass and activity that would bound the large majority of the materials handled in the laboratory in one year. The radionuclide distribution in the $30 \mathrm{~kg}$ sample of SS is shown in Table 1.

To determine the emission potential from the source term, radionuclide activities in Table 1 were multiplied by appropriate emission factors based on the physical state of the material. Because the material could undergo heating, an alternative to the method in 40 CFR 61 Appendix D, approved for use at INL by EPA Region 10 )see letter from Donald Dossett [EPA Region 10] to Tim Safford [DOE-ID] Oct 19, 2017 [CCN 241475]) was used to determine the emission factors for radioactive solid materials with high melting and boiling points. These emission factors are:

- 1 for radioactive solid materials heated to temperatures greater than or equal to $90 \%$ of the boiling or subliming point;

- $10^{-3}$ for radioactive solid materials heated to temperatures greater than or equal to their melting point but less than $90 \%$ of their boiling or subliming point; and

- $10^{-6}$ for radioactive solid materials heated to temperatures above ambient temperature but less than their melting point. 
TEM-10200-1

$12 / 19 / 17$

Rev. 08

ENGINEERING CALCULATIONS AND ANALYSIS

Page 7 of 17

Estimation of dose from potential radionuclide emissions from the Sample Preparation

Title: $\quad$ Laboratory at the Materials and Fuels Complex

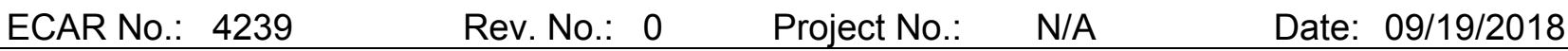

Melting points and boiling points were taken from the CRC Handbook of Chemistry and Physics, 99 Edition (2018). Melting points and $90 \%$ of boiling points are shown in Table 1. Emission factors were determined for each radionuclide over a temperature range between 20 and $4300^{\circ} \mathrm{C}$ which is greater than the $90 \%$ boiling point for all radionuclides. These emission factors are provided in Appendix A.

Table 1. Radionuclide activities and physical properties for determining emissions potential.

\begin{tabular}{|c|c|c|c|}
\hline Radionuclide & $\begin{array}{c}\text { Activity in 30kg Type } \\
316 \text { SS Sample } \\
\text { After } 30 \text { Days Decay } \\
\text { (Ci) }\end{array}$ & $\begin{array}{l}\text { Melting Point } \\
\text { (C) }\end{array}$ & $\begin{array}{l}90 \% \text { of Boiling } \\
\text { Point }(\mathrm{C})\end{array}$ \\
\hline $\mathrm{Al}-28$ & $5.44 \mathrm{E}-19$ & 660 & 2267 \\
\hline C-14 & $1.01 \mathrm{E}+00$ & $-999^{a}$ & $-999^{a}$ \\
\hline Co-58 & $2.63 E+03$ & 1495 & 2634 \\
\hline Co-60 & $2.02 E+02$ & 1495 & 2634 \\
\hline $\mathrm{Cr}-51$ & $4.04 E+04$ & 1907 & 2404 \\
\hline Cu-64 & $3.93 \mathrm{E}-17$ & 1085 & 2304 \\
\hline Cu-66 & 3.30E-06 & 1085 & 2304 \\
\hline Fe-55 & $2.02 E+04$ & 1538 & 2575 \\
\hline Fe-59 & $1.23 E+03$ & 1538 & 2575 \\
\hline $\mathrm{H}-3$ & 4.42E-04 & $-259^{b}$ & $-227^{b}$ \\
\hline$M n-54$ & $3.82 E+03$ & 1246 & 1855 \\
\hline Mo-93 & $1.01 \mathrm{E}-01$ & 2622 & 4175 \\
\hline Mo-93m & $2.51 \mathrm{E}-31$ & 2622 & 4175 \\
\hline Mo-99 & $4.00 \mathrm{E}+00$ & 2622 & 4175 \\
\hline $\mathrm{Nb}-92$ & $4.88 \mathrm{E}+00$ & 2477 & 4267 \\
\hline $\mathrm{Nb}-94$ & $1.51 \mathrm{E}-04$ & 2477 & 4267 \\
\hline $\mathrm{Nb}-95$ & $1.30 \mathrm{E}+00$ & 2477 & 4267 \\
\hline $\mathrm{Nb}-95 \mathrm{~m}$ & $3.54 \mathrm{E}-03$ & 2477 & 4267 \\
\hline $\mathrm{Nb}-96$ & 7.75E-10 & 2477 & 4267 \\
\hline $\mathrm{Nb}-97$ & $2.41 \mathrm{E}-15$ & 2477 & 4267 \\
\hline $\mathrm{Nb}-97 \mathrm{~m}$ & $2.12 \mathrm{E}-15$ & 2477 & 4267 \\
\hline $\mathrm{Ni}-59$ & $2.98 \mathrm{E}+00$ & 1455 & 2622 \\
\hline $\mathrm{Ni}-63$ & 4.39E+02 & 1455 & 2622 \\
\hline $\mathrm{Ni}-66$ & 3.29E-06 & 1455 & 2622 \\
\hline P-32 & $4.32 \mathrm{E}+01$ & 44 & 252 \\
\hline P-33 & 3.05E-03 & 44 & 252 \\
\hline Ru-103 & 7.33E-01 & 1963 & 3326 \\
\hline S-35 & $2.92 \mathrm{E}+00$ & 115 & 400 \\
\hline Sc- 47 & 6.81E-06 & 1541 & 2552 \\
\hline Sc-48 & 4.18E-08 & 1541 & 2552 \\
\hline Tc-99 & 3.93E-03 & 2157 & 3836 \\
\hline Y-89m & 3.28E-04 & 1522 & 3011 \\
\hline$Y-90$ & 4.60E-07 & 1522 & 3011 \\
\hline Zn-65 & 6.49E-04 & 420 & 816 \\
\hline Zr-89 & 3.28E-04 & 1854 & 3965 \\
\hline Zr-95 & 4.77E-01 & 1854 & 3965 \\
\hline Zr-97 & $2.24 \mathrm{E}-15$ & 1854 & 3965 \\
\hline
\end{tabular}

a. $\quad \mathrm{C}-14$ modeled as $\mathrm{CO}_{2}$, therefore low melting and boiling points assigned to be considered gas at any temperature.

b. $\mathrm{H}-3$ assigned melting and boiling points for tritium gas ( $\mathrm{HT}$ or $\mathrm{T}_{2}$ ). 
Rev. 08

Estimation of dose from potential radionuclide emissions from the Sample Preparation

Title: $\quad$ Laboratory at the Materials and Fuels Complex

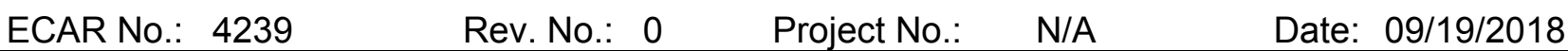

For this analysis, doses were calculated for unmitigated and mitigated emissions. Credit for HEPA filtration (mitigated) was accounted for by applying an additional emission factor of 0.01 to the source term activity if the temperature to which the material is heated is less than the melting point. This adjustment is allowed for particulates per Appendix D of 40 CFR 61, "Methods for Estimating Radionuclide Emissions."

\section{Atmospheric Dispersion Modeling}

Air-dispersion modeling of radionuclide emissions from SPL to potential public receptor locations was conducted according to guidance for performing environmental compliance-driven air modeling of emissions from INL facilities (Staley et al. 2004). The modeling entailed calculating annual doses (in $\mathrm{mrem} / \mathrm{year}$ ) for unit emission rates $(1 \mathrm{Ci} / \mathrm{year}$ ) for each of the radionuclides listed in Table 1 using the computer model CAP88-PC Version 4 (EPA 2013a). Unit dose factors (mrem/Ci) were calculated for each of the sixty-two INL Site NESHAP receptor locations that encircle the INL Site boundary (see Figure 1). Radionuclides were assumed to be released from a single ground-level point source with no momentum or buoyant plume rise.

Unit dose factors are used because the CAP88-PC simulations only have to be done once for each radionuclide. The unit dose factors are multiplied by radionuclide emission rates to get the dose for each radionuclide without having to run CAP88-PC for each temperature-dependent emission rate. The total dose is, then, the sum of the individual radionuclide doses.

The unit dose factor is the annual effective dose equivalent at a specific location for a unit (1 Ci/year) release and is given by:

$$
U D F_{i, j}=\frac{D_{i, j}}{Q_{i}}
$$

where:

$U D F_{i, j}=$ unit dose factor for radionuclide $i$ (including progeny), at receptor $j$ (mrem/Ci)

$D_{i, j}=$ CAP88-PC total pathway parent/progeny annual effective dose equivalent for radionuclide $i$, at receptor $j$ (mrem/year)

$Q_{i}=$ unit release rate for radionuclide $i,(1 \mathrm{Ci} /$ year).

The unit dose factors include the effects of ingestion, inhalation, air immersion, and radiation from ground surface. Doses were calculated using the local food-production option in CAP88-PC to simulate a rural subsistence-farming scenario for the public receptors. This is conservative because it assumes most of the food products consumed are grown in the assessment area, which is unlikely. The CAP88PC Version 4.0 default parameters for this exposure scenario are shown in Table 2. 
TEM-10200-1

$12 / 19 / 17$

ENGINEERING CALCULATIONS AND ANALYSIS

Page 9 of 17

Rev. 08

Estimation of dose from potential radionuclide emissions from the Sample Preparation

Title: $\quad$ Laboratory at the Materials and Fuels Complex

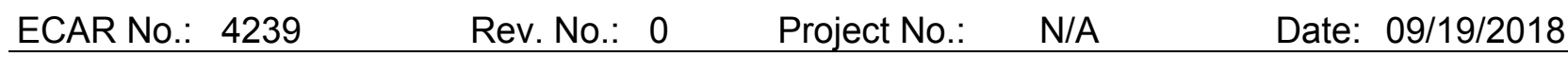

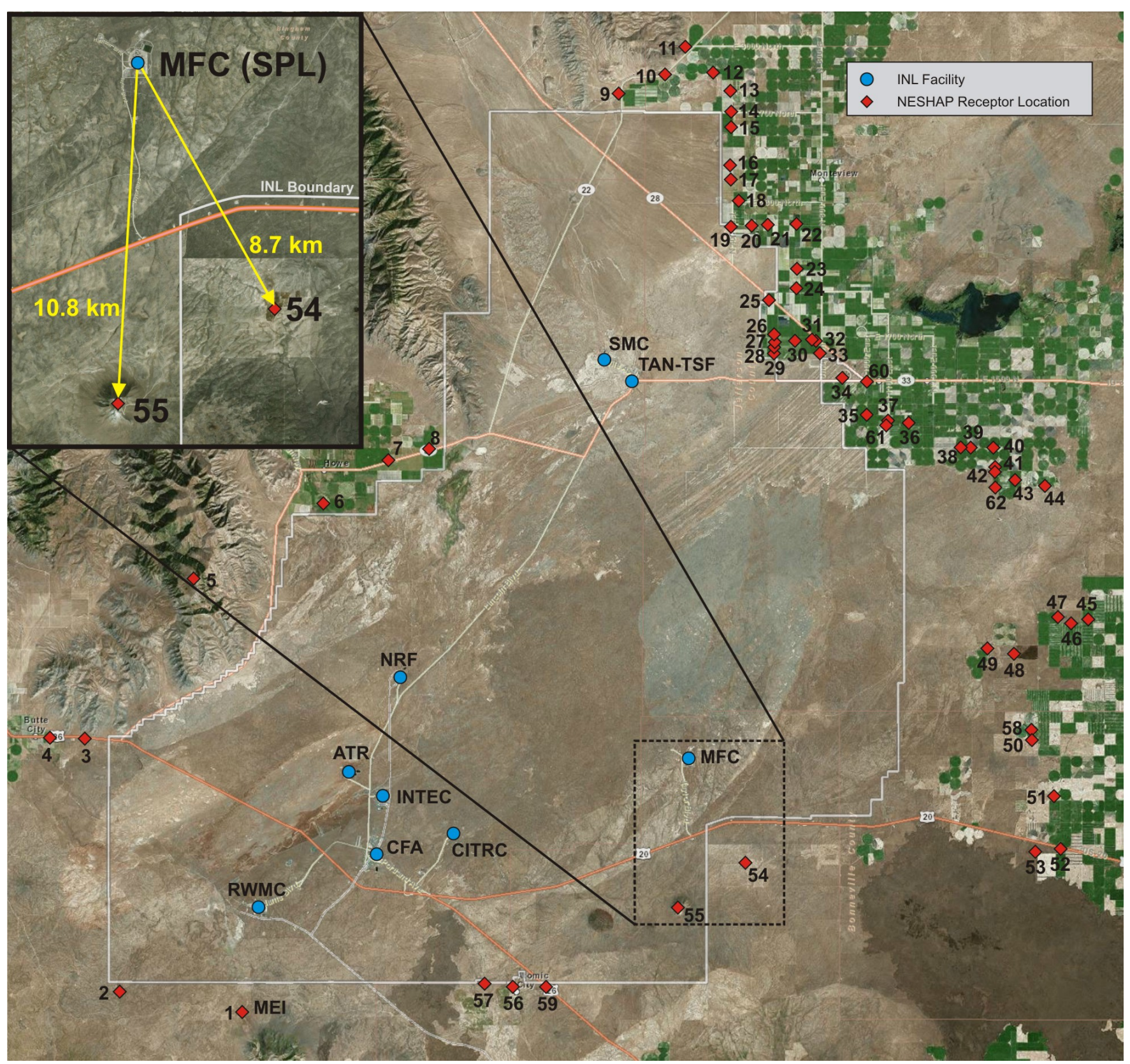

Figure 1. INL NESHAP public receptor locations. Locations 54 and 55 are the locations nearest (see inset). 
Rev. 08

Estimation of dose from potential radionuclide emissions from the Sample Preparation

Title: $\quad$ Laboratory at the Materials and Fuels Complex

$\begin{array}{lllll}\text { ECAR No.: } 4239 & \text { Rev. No.: } 0 & \text { Project No.: N/A Date: 09/19/2018 }\end{array}$

A meteorological data file provided by the Idaho Falls Office of the National Oceanic and Atmospheric Administration (NOAA) was used as input to CAP88-PC. Meteorological monitoring stations are located near each of the major INL facilities. The meteorological data file represents average wind conditions over a 10-year (2006-2015) period from the lower $(10 \mathrm{~m})$ measurement height of the EBR station located immediately east of MFC. A stability array ( ${ }^{*}$.str) file provided by NOAA was converted to a wind ( ${ }^{*}$.wnd) file using the computer program WINDGET. The wind file is presented in Appendix B. Other meteorological data used in the modeling is provided in Table 3.

For most of the radionuclides modeled, there is only one chemical form option in CAP88-PC, and that is particulate. All radionuclides were simulated as their default chemical form in CAP88-PC, with the exception of $\mathrm{C}-14$, which was modeled as gaseous $\mathrm{CO}_{2}$. The default chemical form for $\mathrm{C}-14$ is particulate, but the gas forms $\mathrm{CO}$ and $\mathrm{CO}_{2}$ produce equal, but slightly higher doses than the particulate form. The default form for $\mathrm{H}-3$ is HTO vapor which, for the conditions modeled, results in a higher dose than the particulate or gaseous form. For other radionuclides for which a chemical form other than particulate is an option ( $\mathrm{S}, \mathrm{Ni}, \mathrm{Ru}$ ), the particulate form produces a higher dose than any other forms, so it was used.

Development of CAP88-PC input files and execution of code were performed using three Perl Scripts. The first script (mkFiles.pl) creates the CAP88-PC input files using a facility-specific template file and radionuclide-specific template files for radionuclides listed in the file NucList.inp. The MFC-facility template file contains the file path and name of the wind file, receptor distances, model options, release parameters, and other meteorological data (see Table 3). The radionuclide template files were created with the graphical-user-interface version of CAP88-PC, one at a time, using generic facility data. After creating each file, the generic facility-specific information was removed so the file could be combined with the MFC-facility template file using the mkFiles.p/ script. Each radionuclide template file contains radionuclide-specific data, including half-life and decay chain information, deposition velocity and scavenging coefficient, food transfer factors, radionuclide solubility class, and particle size. CAP88-PC default parameter values were used in all radionuclide template files with one exception. C-14 was modeled as $\mathrm{CO}_{2}$ gas because the dose for $\mathrm{CO}_{2}$ is greater than particulate default form.

The second script (runFiles.pl) makes each CAP88-PC run for all files in the NucFiles.inp file. After each simulation, runFiles.pl copies the summary output file ( ${ }^{*}$.SUM) for each radionuclide to the appropriate directory. The third script (getCAP88dose2.pl) post-processes all the *.SUM files listed in OutputFiles.inp. The script extracts the total dose result from the CAP88 *.SUM files and writes the output to a text file (tempdoses.txt) containing facility name, radionuclide, receptor distance and direction, and unit dose factor. Copies of the three Perl scripts and required input files are included in Appendix C. It should be noted that the Perl scripts are not necessary, but are used for convenience due to the number of model runs. The veracity of the scripts can easily be checked, and several random checks were performed. 
Rev. 08

\author{
Estimation of dose from potential radionuclide emissions from the Sample Preparation
}

Title: $\quad$ Laboratory at the Materials and Fuels Complex

$\begin{array}{lllll}\text { ECAR No.: } 4239 & \text { Rev. No.: } & 0 & \text { Project No.: N/A } & \text { Date: } 09 / 19 / 2018\end{array}$

Table 2. CAP88-PC Version 4.0 radionuclide-independent parameters for the rural receptor scenario.

\begin{tabular}{|c|c|c|}
\hline Parameter Description & Value & Units \\
\hline Inhalation rate & $5.263 \mathrm{E}+03^{\mathrm{a}}$ & $\mathrm{m}^{3} /$ year \\
\hline Effective surface density of soil, dry weight (assumes $15 \mathrm{~cm}$ plow depth) & 215 & $\mathrm{~kg} / \mathrm{m}^{2}$ \\
\hline Build-up time for radionuclides in soil & 100 & year \\
\hline Build-up time radionuclides deposited on ground/water & $3.65 \mathrm{E}+04$ & day \\
\hline Delay time, ingestion of pasture grass by animals & 0 & $\mathrm{hr}$ \\
\hline Delay time, ingestion of stored feed by animals & 2160 & $\mathrm{hr}$ \\
\hline Delay time, ingestion of leafy vegetables by man & 336 & $\mathrm{hr}$ \\
\hline Delay time, ingestion of produce by man & 336 & $\mathrm{hr}$ \\
\hline Delay time, transport time from animal feed-milk-man & 2 & day \\
\hline Delay time, time from animal slaughter to consumption & 20 & day \\
\hline Removal rate constant for physical loss by weathering & 2.90E-03 & $1 / \mathrm{hr}$ \\
\hline Crop exposure duration, pasture grass & 720 & $\mathrm{hr}$ \\
\hline Crop exposure duration, crops or leafy vegetables & 1440 & $\mathrm{hr}$ \\
\hline Agricultural productivity, grass-cow-milk-man pathway & 0.28 & $\mathrm{~kg} / \mathrm{m}^{2}$ \\
\hline Agricultural productivity, produce/leafy vegetables for human consumption & 0.716 & $\mathrm{~kg} / \mathrm{m}^{2}$ \\
\hline Fallout interception fraction, vegetables & 0.2 & -- \\
\hline Fallout interception fraction, pasture & 0.57 & --- \\
\hline Fraction of year animals graze on pasture & 0.4 & --- \\
\hline Fraction of daily feed that is pasture grass (when animal on pasture) & 0.43 & --- \\
\hline Animal consumption rate of contaminated feed/forage (dry weight) & 15.6 & kg/day \\
\hline Milk production of cow & 11 & L/day \\
\hline Muscle mass of animal at slaughter & 200 & $\mathrm{~kg}$ \\
\hline Fraction of animal herd slaughtered per day & $3.81 \mathrm{E}-03$ & -- \\
\hline Fraction of radioactivity retained after washing (leafy veg \& produce) & 0.5 & --- \\
\hline Fraction of produce ingested grown in garden of interest & 1 & --- \\
\hline Fraction of leafy vegetables ingested grown in garden of interest & 1 & --- \\
\hline Human produce ingestion rate & $76.2^{a}$ & $\mathrm{~kg} /$ year \\
\hline Human milk ingestion rate & $53^{a}$ & L/year \\
\hline Human meat ingestion rate & $84^{a}$ & $\mathrm{~kg} / \mathrm{year}$ \\
\hline Human leafy vegetable ingestion rate & $7.79^{a}$ & $\mathrm{~kg} / \mathrm{year}$ \\
\hline Fraction of time spent swimming & 0 & - \\
\hline Depth of water for dilution for water immersion doses & 1 & $\mathrm{~cm}$ \\
\hline Fraction vegetables home produced & $0.7^{\mathrm{b}}$ & --- \\
\hline Fraction milk home produced & $0.4^{b}$ & --- \\
\hline Fraction meat home produced & $0.44^{b}$ & --- \\
\hline Fraction vegetables from assessment area & $0.3^{b}$ & --- \\
\hline Fraction meat from assessment area & $0.60^{\mathrm{b}}$ & --- \\
\hline Fraction meat from assessment area & $0.56^{b}$ & --- \\
\hline Minimum ingestion fractions from outside area, vegetables & $0^{\mathrm{a}}$ & --- \\
\hline Minimum ingestion fractions from outside area, meat & $0^{a}$ & --- \\
\hline Minimum ingestion fractions from outside area, milk & $0^{a}$ & --- \\
\hline Default beef cattle density & 7.19E-02c & \#/ha \\
\hline Milk cattle density & $8.56 \mathrm{E}-03^{\mathrm{c}}$ & \#/ha \\
\hline Land fraction cultivated for vegetables & $7.15 \mathrm{E}-02^{\mathrm{c}}$ & --- \\
\hline
\end{tabular}
a. Value is changed from CAP88-PC Version 3.0
b. Value for a rural food source option. Options are Urban, Rural, Local, Regional, or Imported.
c. Values specific to the State of Idaho. 
Rev. 08

Estimation of dose from potential radionuclide emissions from the Sample Preparation

Title: $\quad$ Laboratory at the Materials and Fuels Complex

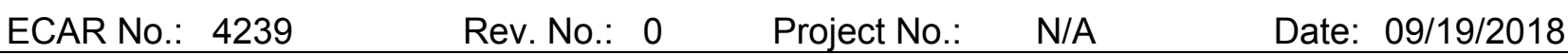

Table 3. Other meteorological parameters used for the CAP88-PC modeling.

\begin{tabular}{lcc}
\hline Variable & Value $^{a}$ & Units \\
\hline Lid height & 800 & meters \\
Mean temperature & 280.2 & Kelvin \\
Annual Precipitation & 20.8 & $\mathrm{~cm} / \mathrm{year}$ \\
Absolute humidity & 3.54 & $\mathrm{~g} / \mathrm{m}^{3}$ \\
\hline
\end{tabular}

a. Values represent a 10-year average at the INL (Clawson et al. 1989).

\section{RESULTS}

\section{Unit Dose Factors}

As might be expected, the maximum dose occurs at the receptor locations nearest the source (locations 54 and 55, see Figure 1). Although receptor location 54 is closer to MFC ( 8.7 km SSE), wind conditions produce equal or slightly higher doses for most radionuclides at receptor location 55 located $\sim 10.8 \mathrm{~km}$ south of MFC at the top of East Butte (see Table 4). Although location 55 is located on the INL Site and there are no permanent residents there, it has been considered as a public receptor site for the annual NESHAP evaluation because of the potential for consistent public or worker presence. For conservatism, the maximum unit dose factor from either location 54 or 55 was used for this assessment although the differences between each location were small. These maximum unit dose factors are provided in the last column of Table 4. These were multiplied by the annual emission estimates (Ci/year) to calculate the estimated doses (mrem/year) as a function of temperature.

\section{Maximum Annual Dose Estimate}

Figure 2 shows the maximum annual dose to a public receptor as a function of temperature if the total mass of material is heated to that temperature. This is not a realistic scenario, but is shown for informational purposes only. This represents both the unmitigated and mitigated cases. They are essentially the same because at any given temperature, the dose is driven by one or a few radionuclides, the boiling points of which have been exceeded; thus, any adjustments to the emission factor for HEPA filtration may not be applied.

The results indicate that if the material is not exposed to temperatures above $1850^{\circ} \mathrm{C}$ (greater than the melting point of Type $316 \mathrm{SS}$ of $1400^{\circ} \mathrm{C}$ ), the dose will be less than $0.05 \mathrm{mrem} /$ year which is significantly less than the $10 \mathrm{mrem} /$ year standard allowed by $40 \mathrm{CFR} 61$, Subpart $\mathrm{H}$, and less than the $0.1 \mathrm{mrem} /$ year limit above which an application to construct or modify is required. At a temperature over $1850^{\circ} \mathrm{C}$, the dose increases to $15.3 \mathrm{mrem} /$ year. This dose is due almost entirely to Mn-54 because at this temperature manganese must be considered a gas (emission factor $=1$ ). The maximum potential dose is $39.2 \mathrm{mrem} /$ year, which occurs at temperatures above $4270^{\circ} \mathrm{C}$ (greater than $90 \%$ of the boiling point of all radionuclides) at which all radionuclides must be considered a gas and released. This can be thought of as the dose if the entire inventory in Table 1 is released each year. 
Rev. 08

Estimation of dose from potential radionuclide emissions from the Sample Preparation

Title: $\quad$ Laboratory at the Materials and Fuels Complex

$\begin{array}{lllll}\text { ECAR No.: } 4239 & \text { Rev. No.: } & 0 & \text { Project No.: N/A } & \text { Date: 09/19/2018 }\end{array}$

Table 4. Radionuclide activities and unit dose factors from CAP88-PC modeling.

\begin{tabular}{|c|c|c|c|c|}
\hline Radionuclide & $\begin{array}{c}\text { Activity in 30kg Type } \\
316 \text { SS Sample } \\
\text { After } 30 \text { Days Decay } \\
\text { (Ci) }\end{array}$ & $\begin{array}{l}\text { Location } 54 \\
\text { Unit Dose } \\
\text { Factor } \\
\text { (mrem/Ci) } \\
\end{array}$ & $\begin{array}{l}\text { Location } 55 \\
\text { Unit Dose } \\
\text { Factor } \\
\text { (mrem/Ci) } \\
\end{array}$ & $\begin{array}{c}\text { Maximum Unit } \\
\text { Dose Factor from } \\
\text { Location } 54 \text { or } 55 \\
(\mathrm{mrem} / \mathrm{Ci}) \\
\end{array}$ \\
\hline Al-28 & $5.44 \mathrm{E}-19$ & $3.50 \mathrm{E}-12$ & $3.0 \mathrm{E}-13$ & $3.50 \mathrm{E}-12$ \\
\hline$C-14^{a}$ & $1.01 \mathrm{E}+00$ & 4.60E-04 & 4.7E-04 & 4.70E-04 \\
\hline Co-58 & $2.63 E+03$ & 1.20E-03 & 1.3E-03 & 1.30E-03 \\
\hline Co-60 & $2.02 E+02$ & 6.40E-02 & $6.5 \mathrm{E}-02$ & 6.50E-02 \\
\hline Cr-51 & $4.04 \mathrm{E}+04$ & 1.80E-05 & $1.8 \mathrm{E}-05$ & 1.80E-05 \\
\hline Cu-64 & $3.93 \mathrm{E}-17$ & 3.70E-06 & 3.7E-06 & 3.70E-06 \\
\hline Cu-66 & 3.30E-06 & $4.00 \mathrm{E}-10$ & $1.5 \mathrm{E}-10$ & $4.00 \mathrm{E}-10$ \\
\hline $\mathrm{Fe}-55$ & $2.02 \mathrm{E}+04$ & 1.90E-04 & $1.9 \mathrm{E}-04$ & 1.90E-04 \\
\hline Fe-59 & $1.23 E+03$ & 1.10E-03 & $1.2 \mathrm{E}-03$ & 1.20E-03 \\
\hline $\mathrm{H}-3_{\mathrm{b}}$ & 4.42E-04 & 9.30E-06 & $9.5 \mathrm{E}-06$ & 9.50E-06 \\
\hline$M n-54$ & $3.82 E+03$ & 3.90E-03 & 4.0E-03 & 4.00E-03 \\
\hline Mo-93 & 1.01E-01 & 2.40E-03 & 2.4E-03 & 2.40E-03 \\
\hline Mo-93m & 2.51E-31 & 2.00E-05 & 2.0E-05 & 2.00E-05 \\
\hline Mo-99 & $4.00 \mathrm{E}+00$ & 2.70E-05 & $2.8 \mathrm{E}-05$ & 2.80E-05 \\
\hline $\mathrm{Nb}-92$ & $4.88 \mathrm{E}+00$ & 2.40E-01 & $2.5 \mathrm{E}-01$ & $2.50 \mathrm{E}-01$ \\
\hline $\mathrm{Nb}-94$ & $1.51 \mathrm{E}-04$ & 2.50E-01 & 2.6E-01 & 2.60E-01 \\
\hline $\mathrm{Nb}-95$ & $1.30 \mathrm{E}+00$ & 4.60E-04 & 4.7E-04 & 4.70E-04 \\
\hline $\mathrm{Nb}-95 \mathrm{~m}$ & 3.54E-03 & 5.50E-05 & 5.6E-05 & 5.60E-05 \\
\hline $\mathrm{Nb}-96$ & 7.75E-10 & 5.50E-05 & 5.6E-05 & 5.60E-05 \\
\hline $\mathrm{Nb}-97$ & $2.41 \mathrm{E}-15$ & 1.70E-06 & $1.5 \mathrm{E}-06$ & 1.70E-06 \\
\hline $\mathrm{Nb}-97 \mathrm{~m}^{\mathrm{c}}$ & $2.12 \mathrm{E}-15$ & NA & NA & NA \\
\hline $\mathrm{Ni}-59^{d}$ & $2.98 \mathrm{E}+00$ & 8.80E-05 & 8.9E-05 & 8.90E-05 \\
\hline $\mathrm{Ni}-63^{d}$ & $4.39 E+02$ & 1.80E-04 & 1.8E-04 & 1.80E-04 \\
\hline $\mathrm{Ni}-66^{\mathrm{d}}$ & 3.29E-06 & 4.60E-05 & 4.7E-05 & 4.70E-05 \\
\hline P-32 & $4.32 \mathrm{E}+01$ & 2.90E-04 & $2.9 \mathrm{E}-04$ & 2.90E-04 \\
\hline P-33 & 3.05E-03 & 6.50E-05 & 6.6E-05 & 6.60E-05 \\
\hline $\mathrm{Ru}-103^{\mathrm{d}}$ & 7.33E-01 & 3.80E-04 & 3.9E-04 & 3.90E-04 \\
\hline $\mathrm{S}-35^{\mathrm{e}}$ & $2.92 E+00$ & 2.50E-04 & $2.5 \mathrm{E}-04$ & 2.50E-04 \\
\hline Sc-47 & 6.81E-06 & 1.60E-05 & 1.6E-05 & 1.60E-05 \\
\hline Sc-48 & 4.18E-08 & $1.20 \mathrm{E}-04$ & $1.2 \mathrm{E}-04$ & 1.20E-04 \\
\hline Tc-99 & 3.93E-03 & 1.20E-02 & $1.2 \mathrm{E}-02$ & $1.20 \mathrm{E}-02$ \\
\hline Y-89m & 3.28E-04 & 7.10E-20 & $3.1 \mathrm{E}-20$ & 7.10E-20 \\
\hline$Y-90$ & 4.60E-07 & 2.90E-05 & 2.9E-05 & 2.90E-05 \\
\hline Zn-65 & 6.49E-04 & 7.70E-03 & 7.9E-03 & 7.90E-03 \\
\hline Zr-89 & $3.28 \mathrm{E}-04$ & 7.10E-05 & 7.2E-05 & 7.20E-05 \\
\hline Zr-95 & 4.77E-01 & 1.60E-03 & 1.6E-03 & 1.60E-03 \\
\hline Zr-97 & $2.24 \mathrm{E}-15$ & 3.70E-05 & $3.8 \mathrm{E}-05$ & 3.80E-05 \\
\hline \multicolumn{5}{|c|}{$\begin{array}{l}\mathrm{C}-14 \text { modeled as } \mathrm{CO}_{2} \text { gas. Dose for } \mathrm{CO}_{2} \text { is greater than particulate default form. } \\
\mathrm{H}-3 \text { modeled as } \mathrm{HTO} \text { vapor (default) which produces greater dose than particulate or gas form. } \\
\mathrm{Nb}-97 \mathrm{~m} \text { is not included in the CAP88-PC database likely due to short half-life (52.7 seconds). } \\
\text { Vapor chemical form is an option in CAP88-PC, but modeled as default particulate form which results in greater dose. } \\
\text { Sulfur dioxide }\left(\mathrm{SO}_{2}\right) \text { and carbon disulfide }\left(\mathrm{CS}_{2}\right) \text { chemical forms are options in CAP88-PC, but modeled as default particulate form which } \\
\text { results in greater dose. }\end{array}$} \\
\hline
\end{tabular}


Rev. 08

Estimation of dose from potential radionuclide emissions from the Sample Preparation

Title: $\quad$ Laboratory at the Materials and Fuels Complex

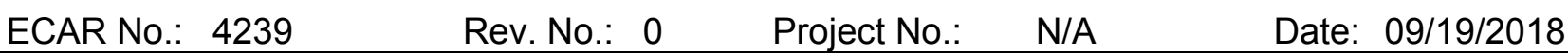

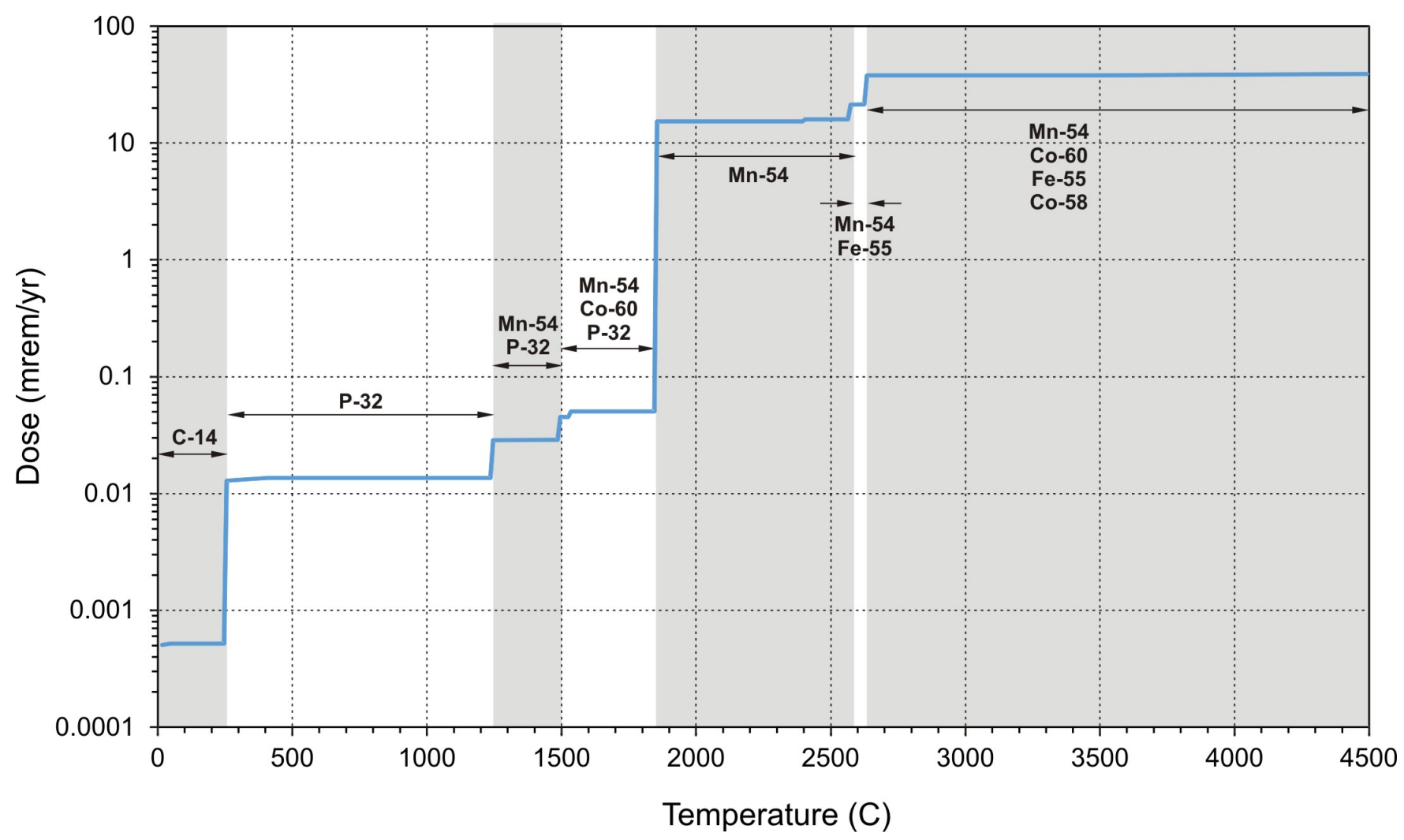

Figure 2. Annual dose (mrem/year) as a function of the temperature to which the material is heated. The radionuclides that dominate the dose for each temperature interval are shown on the figure.

As stated previously, the results in Figure 2 are unrealistic because they assume the entire source term is heated to that temperature when, in reality, only a very small percentage of the source term will be exposed to temperatures above room temperature. Activities such as cutting (with a low-speed saw), grinding, and mechanical-properties testing of samples may cause elevated local temperatures, but the temperatures are expected to be less than $100^{\circ} \mathrm{C}$, and far less than the melting point of the steel $\left(\sim 1400^{\circ} \mathrm{C}\right)$. The only process that would cause local temperatures to exceed $1400^{\circ} \mathrm{C}$ is electricaldischarge machining (EDM). EDM is a controlled metal-removal process that is used to remove metal by means of electric spark erosion. In this process an electric spark (which can cause temperatures to reach $8000^{\circ} \mathrm{C}$ ) is used as the cutting tool to cut the sample. Although the process takes place in a dielectric fluid and no releases are expected to occur, the regulations require the material exposed to EDM to all be released (emission factor $=1$ ) for purposes of calculating dose.

The volume $(V)$ of material expected to be exposed to EDM annually can be approximated as the cut (kerf) volume from making 100 cuts of $1 / 2$ in. tubing $(O D=0.5 \mathrm{in}$. [1.27 cm]) with $1 / 8 \mathrm{in}$. wall thickness $(I D=1 / 4$ in. $[0.635 \mathrm{~cm}])$ and a kerf width $(W)$ of $0.021 \mathrm{~cm}$.

$$
V=\left[\frac{\pi}{4}\left(O D^{2}-I D^{2}\right) \times W\right] \frac{\mathrm{cm}^{3}}{\mathrm{cut}} \times 100 \frac{\mathrm{cuts}}{\mathrm{yr}}=\frac{\pi}{4}\left(1.27^{2}-0.635^{2}\right) \times 0.021 \times 100=2 \frac{\mathrm{cm}^{3}}{\mathrm{yr}}
$$

Given a density of $8 \mathrm{~g} / \mathrm{cm}^{3}$ for Type $316 \mathrm{SS}$, the mass of material impacted by EDM annually is approximately $0.016 \mathrm{~kg}$. 
Rev. 08

Estimation of dose from potential radionuclide emissions from the Sample Preparation

Title: $\quad$ Laboratory at the Materials and Fuels Complex

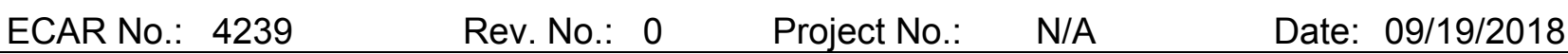

$$
\text { Mass }=\rho \times V=8 \frac{\mathrm{g}}{\mathrm{cm}^{3}} \times 2 \frac{\mathrm{cm}^{3}}{\mathrm{yr}}=16 \frac{\mathrm{g}}{\mathrm{yr}} \text { or } 0.016 \frac{\mathrm{kg}}{\mathrm{yr}} \text {. }
$$

Thus the fraction of the source term expected to be exposed each year to EDM is $0.016 \mathrm{~kg} / 30 \mathrm{~kg}=0.00053$ $(0.053 \%)$. The dose from releasing the activity in $16 \mathrm{~g}$ of kerf material is $0.021 \mathrm{mrem} / \mathrm{year}$. This is shown on Figure 3 as a dashed red line because it is not a function of temperature. An emission factor of 1 is used for this material. The dose from the $99.947 \%$ of the source term that is not exposed to EDM, but could potentially be heated to any temperature less than or equal to $1400 \mathrm{C}$, is shown by the solid blue line. This is essentially the same line from Figure 2. The total dose is the solid purple line which is simply the sum of the solid blue line and the dashed red line. The maximum dose is $0.05 \mathrm{mrem} / \mathrm{year}$ and occurs only if the material not exposed to EDM is heated to temperatures greater than about $1250^{\circ} \mathrm{C}$ and less than $1400^{\circ} \mathrm{C}$.

Figure 3 shows that from $\mathrm{T}=0^{\circ} \mathrm{C}$ to about $250^{\circ} \mathrm{C}$, the dose is dominated by the material exposed to EDM. From 250 to $1250^{\circ} \mathrm{C}$ the dose is due mostly to the activity in the EDM material, with a small contribution from P-32 from activity in the non-EDM material. This is because $90 \%$ of the boiling point for phosphorus is $252^{\circ} \mathrm{C}$, and above that temperature, the emission factor for phosphorus changes from 0.001 to 1 . Above $1250^{\circ} \mathrm{C}$, the dose is due mostly to the activity in EDM material and the Mn-54 and P-32 activity in the non-EDM material. The melting point of manganese is $1242^{\circ} \mathrm{C}$, and above that temperature, the emission factor for Mn-54 changes from 1E-06 to 0.001 . The dose from activity in the EDM material is due to the same radionuclides from Figure 2, which dominate the dose at high temperatures (Co-58 [9\%], Co-60 [34\%], Fe-55 [10\%] and Mn-54 [39\%]).

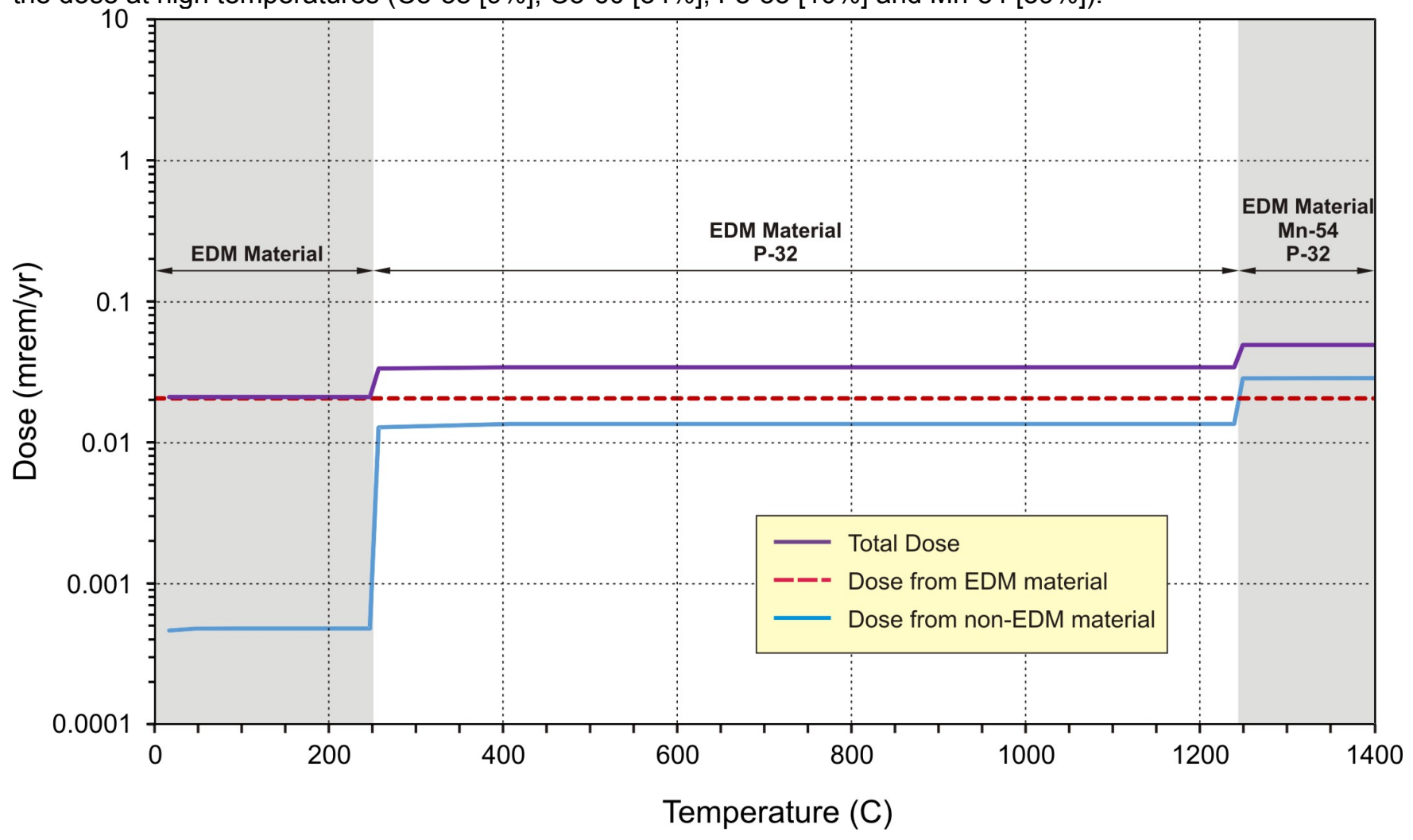

Figure 3. Annual total dose (mrem/year) for non-EDM material as function of temperature and the EDM material (heated to very high temperature). Radionuclides from the non-EDM material that contribute significantly to the dose are shown on the figure for each temperature range.

Calculations were performed to determine the amount of material that could be impacted by EDM and keep the total dose less than $0.1 \mathrm{mrem} /$ year (i.e., $1 \%$ of the regulatory limit). The calculations show that 
Rev. 08

Estimation of dose from potential radionuclide emissions from the Sample Preparation

Title: $\quad$ Laboratory at the Materials and Fuels Complex

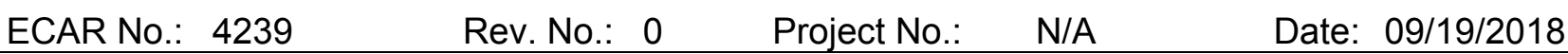

the mass of EDM material could be as high as $56 \mathrm{~g}$, and the total dose would not exceed

$0.1 \mathrm{mrem} /$ year, even if the non-EDM material were heated to $1400^{\circ} \mathrm{C}$, the melting point of the stainless steel (see Figure 4). Fifty-six grams of material is 3.5 times the expected kerf volume and less than $0.2 \%$ of the source term mass.

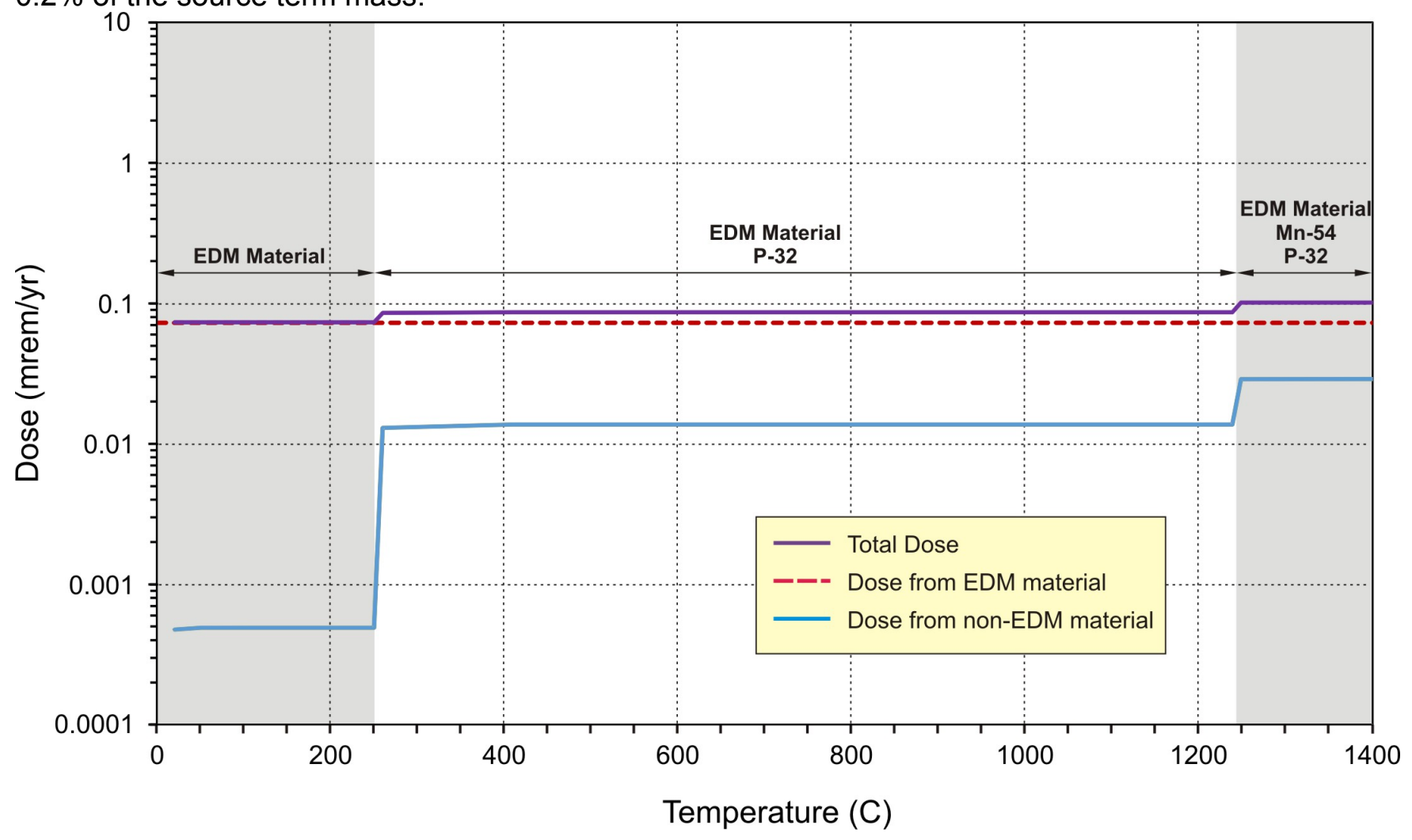

Figure 4. Annual total dose (mrem/year) from non-EDM material as function of temperature and EDM material (heated to very high temperature). Radionuclides from the non-EDM material that contribute significantly to the dose are shown on the figure for each temperature range.

\section{CONCLUSION}

Potential radionuclide emissions from anticipated operations at SPL and subsequent doses from low-level chronic exposure were estimated using methodologies and assumptions consistent with 40 CFR 61, Appendix D and additional guidance and approval by EPA Region 10 (see Dossett to Safford, CCN 241475) for solid materials that undergo heating. The annual source term was represented and assumed bounded by the radionuclide activities in $30 \mathrm{~kg}$ of Type 316 stainless steel irradiated to a fluence of $5 \times 10^{21}$ neutrons $/ \mathrm{cm}^{2}$, with a decay time of 30 days (ECAR-4023 2018). The EPA-approved computer code CAP88PC was used to model atmospheric dispersion and calculate dose at potential public receptor locations.

The potential maximum dose to a member of the public was calculated to be $0.02 \mathrm{mrem} / \mathrm{year}$, based on an estimated $16 \mathrm{~g}$ of the $30 \mathrm{~kg}$ source term $(0.053 \%)$ being exposed to very high temperatures associated with EDM and the remaining material heated to $100^{\circ} \mathrm{C}$. Calculations show the maximum dose could be as high as $0.05 \mathrm{mrem} /$ year if the remaining material were heated to $1400^{\circ} \mathrm{C}$, the melting point of stainless steel. 
Rev. 08

Title:

Estimation of dose from potential radionuclide emissions from the Sample Preparation

Laboratory at the Materials and Fuels Complex

$\begin{array}{lllll}\text { ECAR No.: } 4239 & \text { Rev. No.: } 0 & \text { Project No.: } & \text { N/A } & \text { Date: 09/19/2018 }\end{array}$

The potential maximum dose to a public receptor from emissions at SPL is not expected to exceed $0.1 \mathrm{mrem} /$ year, one percent of the standard, so long as the material impacted by EDM does not exceed $56 \mathrm{~g}$ (3.5 times the expected mass of $16 \mathrm{~g}$ and less than $0.2 \%$ of the total source term) and the remaining material is not heated to temperatures greater than $1400^{\circ} \mathrm{C}$.

It should be noted that credit for HEPA filtration does not impact the dose results because the dose is dominated by radionuclides that have exceeded their boiling point; thus, no credit for HEPA filtration may be applied to the emission factor.

\section{APPENDIXES}

Appendix A, Emission Factors

Appendix B, CAP88-PC Windfile (EBRL6-15.WND)

Appendix C, Perl Scripts and Input Files for Pre- and Post-Processing: CAP88-PC Input/Output

\section{REFERENCES}

40 CFR 61, Subpart H, 2010, "National Emission Standards for Emissions of Radionuclides Other than Radon from Department of Energy Facilities," Code of Federal Regulations, Office of the Federal Register, April 2010.

CCN 241475, 2017, "Letter from Donald Dossett (U.S. EPA Region 10) to Tim Safford (U.S. DOE Idaho Operations Office), Oct 19, 2017.

CRC Handbook of Chemistry and Physics, 99th Edition (Internet Version 2018), John R. Rumble, editor, CRC Press/Taylor \& Francis, Boca Raton, FL.

Clawson, K. L., G. E. Start, and N. R. Ricks, 1989, Climatography of the Idaho National Engineering Laboratory, DOE/ID-12118, National Oceanic and Atmospheric Administration, Field Research Division, Idaho Falls, ID 83402.

EPA 2013a, "CAP88-PC Version 4.0 User's Guide," Trinity Engineering Associates, Inc., Cincinnati, OH, submitted to U.S. EPA, Office of Radiation and Indoor Air, May 2013.

EPA 2013b, "CAP88-PC Version 4 Testing Report," Revision 1, Trinity Engineering Associates, Inc., Cincinnati, OH, submitted to U.S. EPA Office of Radiation and Indoor Air, June 2013.

Staley, C. S., M. L. Abbott, and P. D. Ritter, 2004, INEEL Air Modeling Protocol, INEEL/EXT-0402511, Idaho National Laboratory, December 2004.S 
TEM-10200-1

$12 / 19 / 17$

Rev. 08

ENGINEERING CALCULATIONS AND ANALYSIS

Page $A 1$ of $A 2$

Estimation of dose from potential radionuclide emissions from the Sample Preparation

Title: $\quad$ Laboratory at the Materials and Fuels Complex

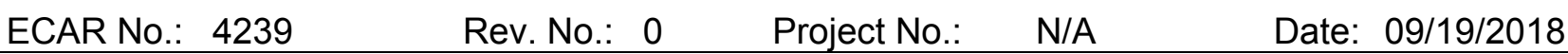

\section{Appendix A}

Emission Factors 
Title: Complex

ECAR No: : 4239

Rev. No.: 0 Project No.: $\mathrm{N} / \mathrm{A}$ Date: $09 / 19 / 2018$

Table A-1. Emission factors for radionuclides in Type 316 stainless steel.

\begin{tabular}{|l|l|l|l|}
\hline \multirow{2}{*}{ Nuclide } & \multicolumn{2}{|c|}{ Temperature (C) } \\
\cline { 2 - 4 } & 20 & 50 & 100 \\
\hline
\end{tabular}

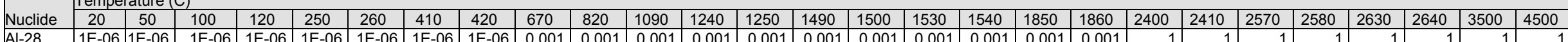

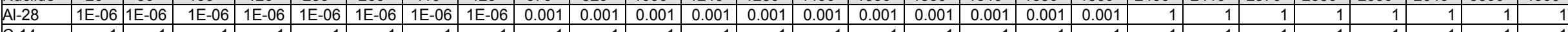

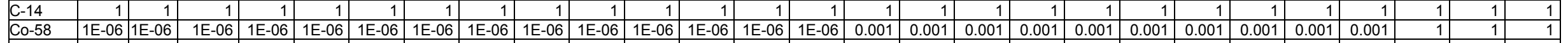

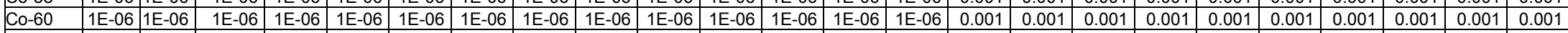

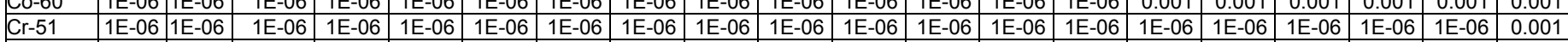

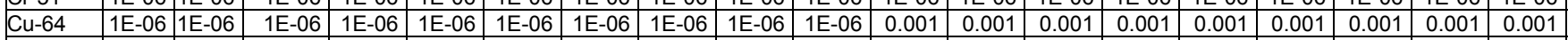

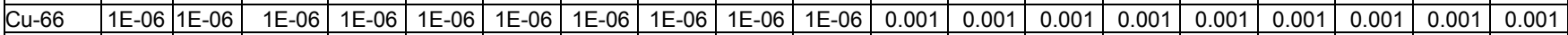

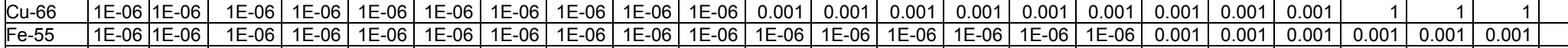

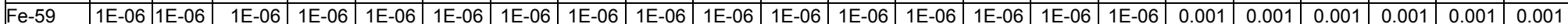

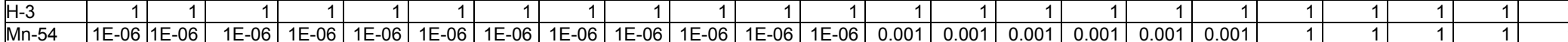

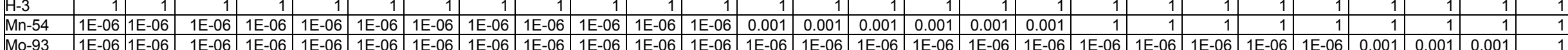

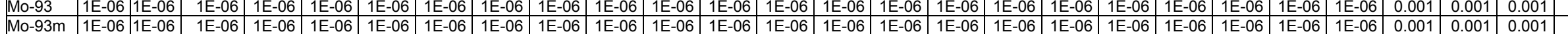

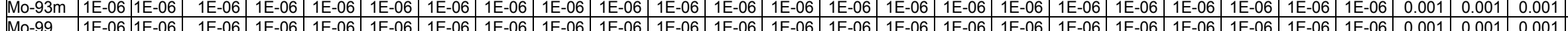

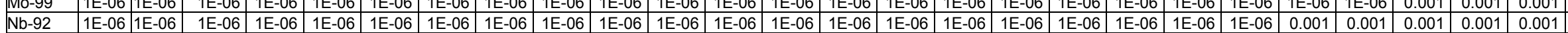

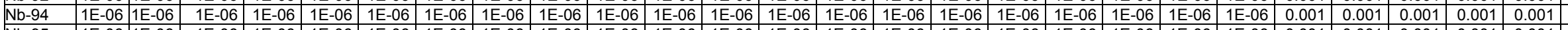

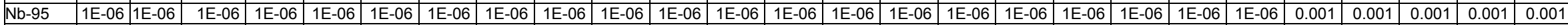

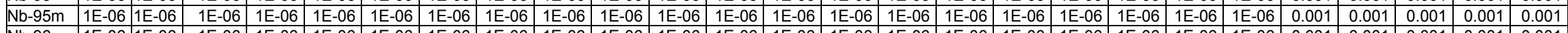

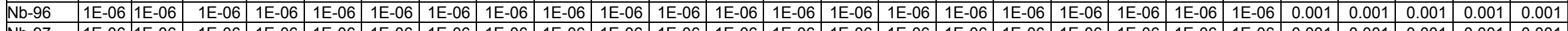

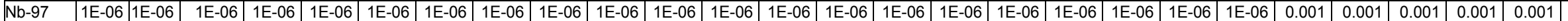

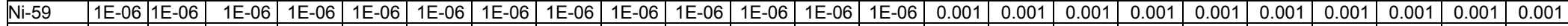

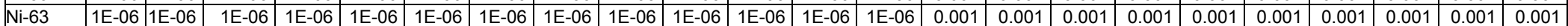

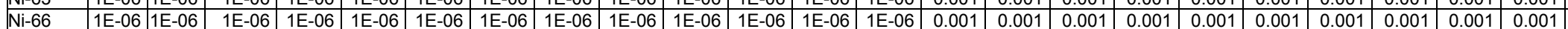

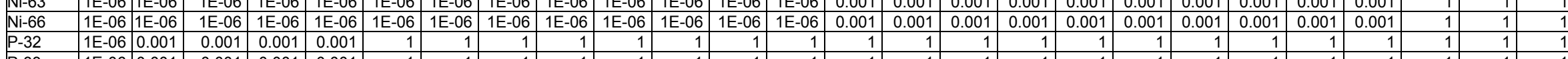

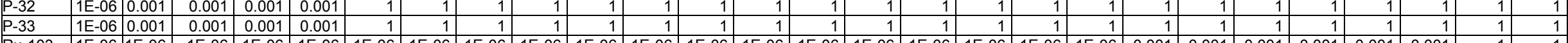

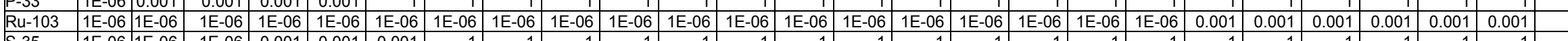

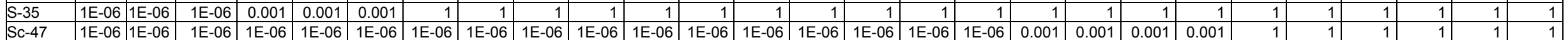

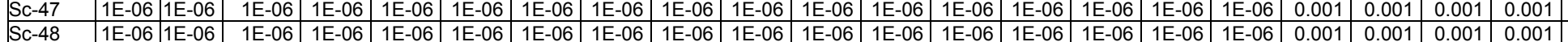

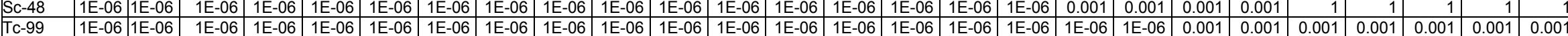

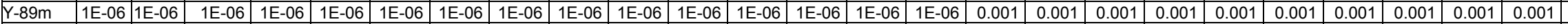

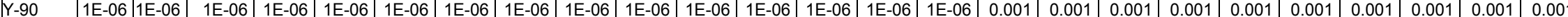

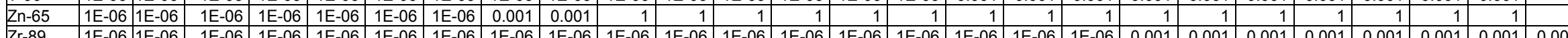

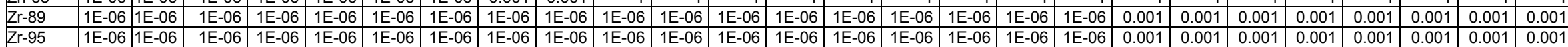

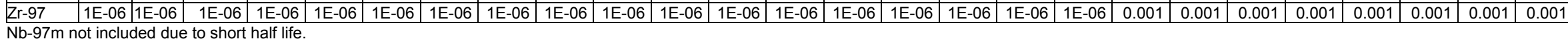


TEM-10200-1

$12 / 19 / 17$

Rev. 08

ENGINEERING CALCULATIONS AND ANALYSIS

Page B1 of B2

Estimation of dose from potential radionuclide emissions from the Sample Preparation

Title: $\quad$ Laboratory at the Materials and Fuels Complex

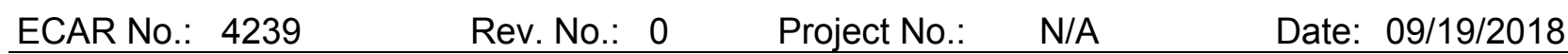

Appendix B

CAP88-PC Windfile (EBRL6-15.WND) 
TEM-10200-1

$12 / 19 / 17$

Rev. 08

ENGINEERING CALCULATIONS AND ANALYSIS

Page B2 of B2

Estimation of dose from potential radionuclide emissions from the Sample Preparation

Title: $\quad$ Laboratory at the Materials and Fuels Complex

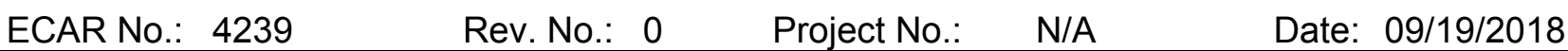

\footnotetext{
4.20349

$\begin{array}{lllllllllllllllll}.0915 & .0608 & .0234 & .0208 & .0366 & .0648 & .0964 & .0821 & .0537 & .0356 & .0253 & .0213 & .0270 & .0720 & .1585 & .1301\end{array}$ 1.5001 .4791 .2991 .3361 .2191 .3401 .4631 .3851 .2961 .2011 .1221 .1761 .3991 .5501 .5081 .509

2.9342 .4472 .1082 .2922 .2701 .7622 .2461 .9591 .7901 .5761 .8262 .3102 .3142 .7672 .8542 .970 4.0353 .5682 .4232 .5462 .4342 .0512 .4482 .3292 .1622 .3113 .0253 .6443 .4263 .4974 .0283 .992 3.5283 .1502 .2242 .1522 .1112 .3993 .0653 .3353 .4973 .3523 .9424 .2544 .0855 .9256 .1514 .929 2.2992 .7871 .7751 .6951 .9492 .1832 .0691 .8771 .3511 .3381 .4941 .7141 .9541 .7232 .1832 .487 1.014 .950 .934 .915 .9331 .0021 .0241 .015 .973 .9561 .001 .9981 .025 .9971 .0331 .020

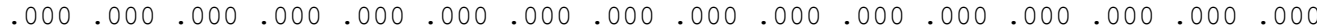
2.0212 .0021 .8161 .8581 .7151 .8621 .9871 .9101 .8131 .6911 .5751 .6561 .9252 .0632 .0282 .028 3.4723 .2182 .9923 .0713 .1322 .6912 .9172 .6222 .4982 .3212 .6972 .9793 .0183 .3523 .4573 .510 4.7034 .2993 .6043 .8063 .6813 .1293 .3443 .0613 .0293 .4374 .0264 .3674 .1304 .2834 .7994 .775 5.4674 .5533 .3843 .4653 .2753 .5624 .3094 .9825 .1984 .8885 .1115 .2165 .1157 .4977 .5166 .495 3.1763 .6532 .8302 .6792 .9102 .9862 .8152 .7161 .9542 .0292 .0422 .2822 .4242 .3893 .1533 .381 1.3851 .2541 .2191 .1741 .2151 .3641 .4061 .3881 .3031 .2671 .3621 .3551 .4071 .3531 .4221 .398

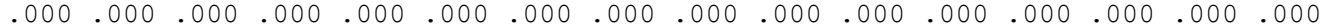
$.0462 \quad .0238$

$.0905 \quad .0312$

$.1118 \quad .0313$

$.0854 \quad .0281$

$.0701 \quad .0329$

$.0732 \quad .0570$

$.0997 \quad .0700$

$.1466 \quad .0853$

$.2236 \quad .0845$

$.3038 \quad .0798$

$.3100 \quad .0874$

$.2765 \quad .1034$

$.0879 \quad .0593$

$.0380 \quad .0339$

$.0328 \quad .0366$

$.0344-.3812$

$.0346 \quad .2215$

$.0308 \quad .2106$

.2106

$.0451 \quad .3648$

$.0984 \quad .4754$

$.1278 \quad .4610$

$.1197 \quad .4346$

$.1013 \quad .3690$

$.0988 \quad .2817$

$.1033 \quad .2438$

$.1075 \quad .2609$

.0924

.0854

.6258

.1034

$.2176 \quad .1203 \quad .0000$

$\begin{array}{lll}.3562 & .1583 & .0000\end{array}$

$\begin{array}{lll}.2356 & .3867 & .0000\end{array}$

$.2034 \quad .4120 \quad .0000$

$\begin{array}{lll}.3028 & .3036 \quad .0000\end{array}$

$\begin{array}{lll}.3118 & .1754 & .0000\end{array}$

$\begin{array}{lll}.1794 & .1166 & .0000\end{array}$

$.1254 \quad .1160 \quad .0000$

$.0737 \quad .1400 \quad .0000$

$\begin{array}{lll}.0595 & .1622 \quad .0000\end{array}$

$.0443 \quad .1916 \quad .0000$

$\begin{array}{lll}.0437 & .2118 & .0000\end{array}$

$.0404 \quad .2113 \quad .0000$

$\begin{array}{lll}.0314 & .1032 & .0000\end{array}$

extended data

.6224

$.0589 \quad .0000$

StationName $=$ EBRL6-15

State $=I D$

Latitude $=0$

Longitude $=0$

TimeZone $=0$

RecordPeriod=

AveragePeriodTemperature $=0$

Comments $=$
} 
TEM-10200-1

$12 / 19 / 17$

Rev. 08

ENGINEERING CALCULATIONS AND ANALYSIS Page C1 of C10

Estimation of dose from potential radionuclide emissions from the Sample Preparation

Title: $\quad$ Laboratory at the Materials and Fuels Complex

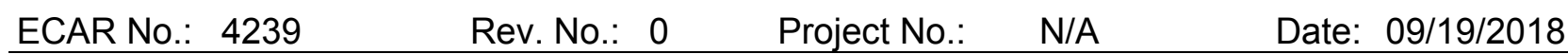

\section{Appendix C}

Perl Scripts and Input Files for Pre- and Post-Processing

CAP88-PC Input/Output 
Rev. 08

\section{Estimation of dose from potential radionuclide emissions from the Sample Preparation}

Title: $\quad$ Laboratory at the Materials and Fuels Complex

ECAR No.: 4239

Rev. No.: 0

Project No::

$\mathrm{N} / \mathrm{A}$

Date: $09 / 19 / 2018$

\section{mkFiles.pl}

\# mkFiles.pl

\# This script inserts the current wind file in the template file and then concatentate the template file

\# with the nuclide file to create all the CAP88 input files. It also replaces the second line of the template

\# file with the filename sans the "dat" (e.g. Ac227A.). A second file is created that is used by subsequent

\# scripts. This file contains a list of nuclide file names and the name of the nuclide

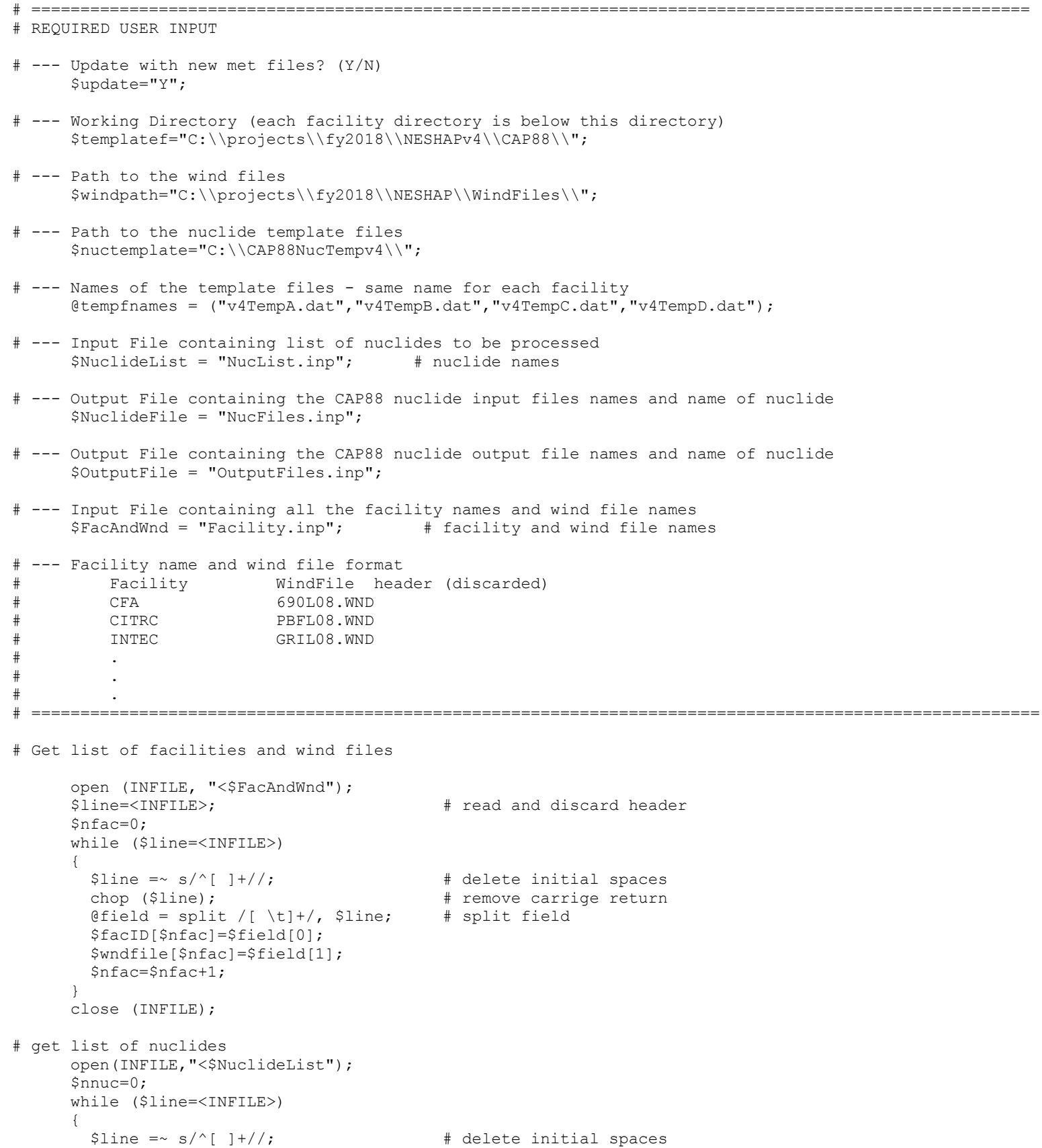


TEM-10200-1

Rev. 08

\section{ENGINEERING CALCULATIONS AND ANALYSIS Page C3 of C10}

\section{Estimation of dose from potential radionuclide emissions from the Sample Preparation}

Title: $\quad$ Laboratory at the Materials and Fuels Complex

$\begin{array}{llllll}\text { ECAR No.: } 4239 & \text { Rev. No.: } & 0 & \text { Project No.: } & \text { N/A } & \text { Date: } 09 / 19 / 2018\end{array}$

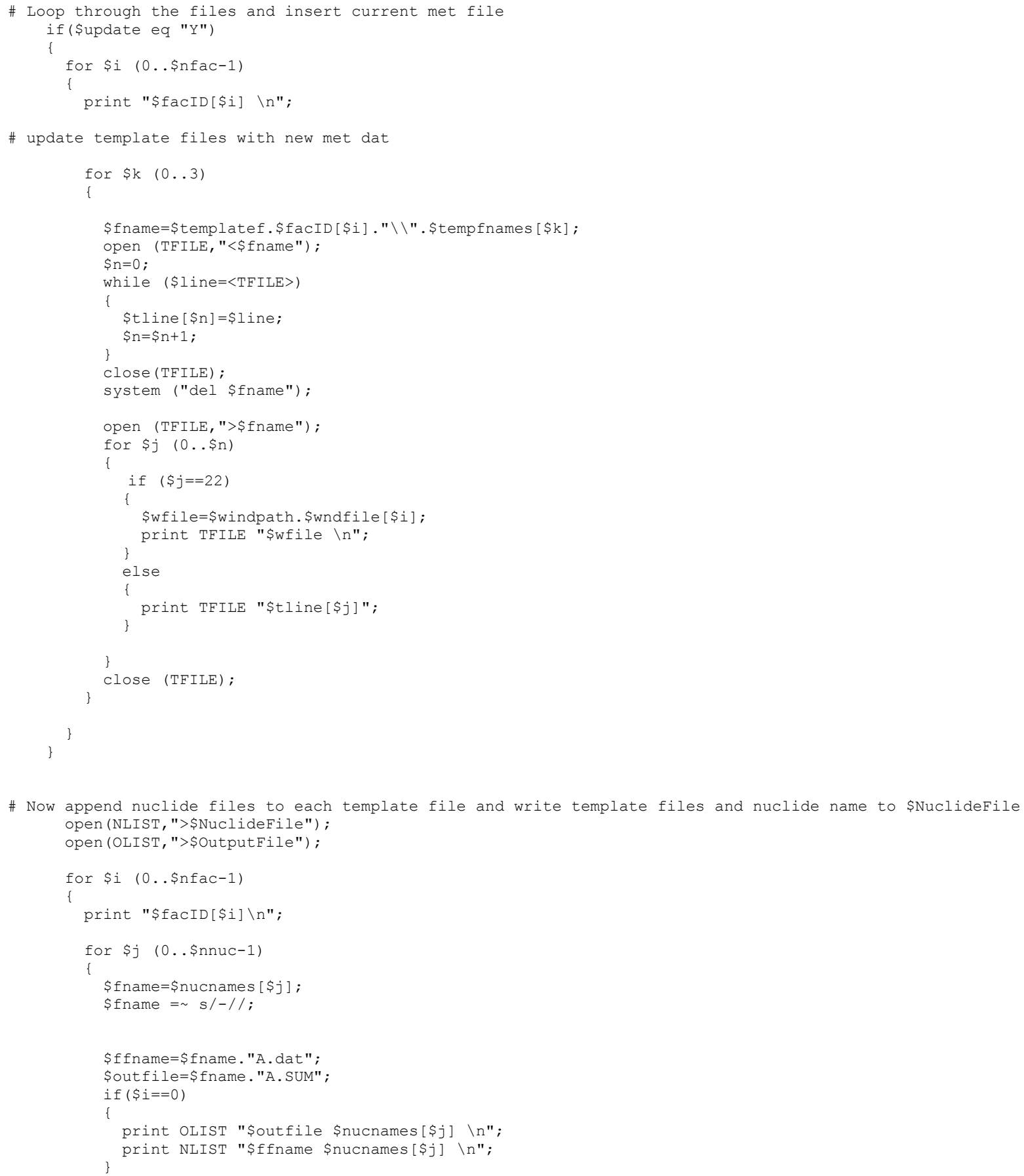


TEM-10200-1

Rev. 08

\section{Estimation of dose from potential radionuclide emissions from the Sample Preparation}

Title: $\quad$ Laboratory at the Materials and Fuels Complex

$\begin{array}{llllll}\text { ECAR No.: } 4239 & \text { Rev. No.: } & 0 & \text { Project No.: } & \text { N/A } & \text { Date: 09/19/2018 }\end{array}$

$\#$

\$ofile=\$templatef.\$facID[\$i]."\\". \$ffname." \n";

\$cmd="del ".\$ofile;

\# print "\$cmd $\backslash \mathrm{n} "$;

system \$cmd;

\#

\$cmd="copy ".\$templatef.\$facID[\$i]."\\".\$tempfnames[0]." + ".\$nuctemplate.\$fname.".dat ".\$ofile;

print "\$cmd \n";

system \$cmd;

\# AJS added following lines to replace 2nd line of cap88 input file with nucname (reqd by v4)

\# Not terribly efficient, but it works. It reads every line of the file, then writes it back replacing line 2 . open (OFILE,"<\$ofile");

$\$ \mathrm{n}=0$;

while (\$line $=<$ OFILE $>$ )

\{

\$zline $[\$ n]=\$ l i n e ;$

close (OFILE) ;

system ("del \$ofile");

open (OFILE,">\$ofile");

for $\$ 1(0 \ldots \$ n)$

\{

if $(\$ 1==1)$

\$capname=\$fname. "A." ;

els

else

\} \}

print OFILE "\$zline[\$1]";

\# AJS End of AJS changes

\$ffname=\$fname."B.dat";

\$outfile=\$fname."B.SUM";

if $(\$ i==0)$

\{

print OLIST "\$outfile \$nucnames[\$j] \n"; \}.

print NLIST "\$ffname \$nucnames[\$j] \n";

\$ofile=\$templatef.\$facID [\$i]." \\".\$ffname." \n";

print "\$cmd $\backslash \mathrm{n} "$;

system \$cmd;

\$cmd="copy ".\$templatef.\$facID[\$i]." \\".\$tempfnames[1]." + ".\$nuctemplate.\$fname.".dat ".\$ofile;

\# print "\$cmd \n";

system \$cmd;

\# AJS added following lines to replace 2nd line of cap88 input file with nucname (reqd by v4)

\# Not terribly efficient, but it works. It reads every line of the file, then writes it back replacing line 2 . open (OFILE,"<\$ofile");

$\$ \mathrm{n}=0$;

while (\$line $=<$ OFILE $>)$

\{

\$zline $[\$ \mathrm{n}]=\$$ line;

\}

$\$ n=\$ n+1$;

close (OFILE) ;

system ("del \$ofile");

open (OFILE,">\$ofile");

for $\$ 1(0 \ldots \$ n)$

if $(\$ 1==1)$

\$capname=\$fname."B." ;

print OFILE "\$capname \n".

else

print OFILE "\$zline[\$1]";

\} 
TEM-10200-1

$12 / 19 / 17$

Rev. 08

ENGINEERING CALCULATIONS AND ANALYSIS Page C5 of C10

Estimation of dose from potential radionuclide emissions from the Sample Preparation

Title: $\quad$ Laboratory at the Materials and Fuels Complex

$\begin{array}{lllll}\text { ECAR No.: } 4239 & \text { Rev. No.: } 0 & \text { Project No.: N/A } & \text { Date: } 09 / 19 / 2018\end{array}$

\# AJS End of AJS changes

\$ffname=\$fname."C.dat";

\$outfile=\$fname."C.SUM";

if $(\$ i==0)$

\{

print OLIST "\$outfile \$nucnames[\$j] \n";

\# AJS added following lines to replace 2nd line of cap88 input file with nucname (regd by v4)

\# Not terribly efficient, but it works. It reads every line of the file, then writes it back replacing line 2. open (OFILE, "<\$ofile");

$\$ \mathrm{n}=0$;

while (\$line $=<$ OFILE $>$ )

\{

\$zline $[\$ n]=\$ l i n e ;$

\}

$\$ \mathrm{n}=\$ \mathrm{n}+1$

close (OFILE) ;

system ("del \$ofile");

open (OFILE, ">\$ofile");

for $\$ 1(0 \ldots \$ n)$

\{

if $(\$ 1==1)$

\$capname=\$fname."C." ;

print OFILE "\$capname $\backslash \mathrm{n} "$

else

print OFILE "\$zline[\$1]";

\# AJS End of AJS changes

\$ffname=\$fname."D.dat";

\$outfile=\$fname."D.SUM"

if $(\$ i==0)$

\{

print OLIST "\$outfile \$nucnames[\$j] \n";

print NLIST "\$ffname \$nucnames[\$j] \n";

\$ofile=\$templatef.\$facID[\$i]." \\".\$ffname." \n";

\$cmd="del ".\$ofile,

print "\$cmd $\backslash n "$,

system \$cmd;

\$cmd="copy ".\$templatef.\$facID[\$i]."\".\$tempfnames[3]." + ".\$nuctemplate.\$fname.".dat ".\$ofile;

\# $\quad$ print "\$cmd $\backslash \mathrm{n} "$;

system \$cmd;

\# AJS added following lines to replace 2nd line of cap88 input file with nucname (reqd by $v 4$ )

\# Not terribly efficient, but it works. It reads every line of the file, then writes it back replacing line 2.

open (OFILE,"<\$ofile");

$\$ \mathrm{n}=0$;

while (\$line=<OFILE $>$

\$zline $[\$ n]=\$$ line;

$\$ n=\$ n+1 ;$

close (OFILE) ;

system ("del \$ofile");

open (OFILE,">\$ofile");

for $\$ 1(0 \ldots \$ n)$

\{

if $(\$ 1==1)$ 
TEM-10200-1

$12 / 19 / 17$

Rev. 08

ENGINEERING CALCULATIONS AND ANALYSIS Page C6 of C10

Estimation of dose from potential radionuclide emissions from the Sample Preparation

Title: $\quad$ Laboratory at the Materials and Fuels Complex

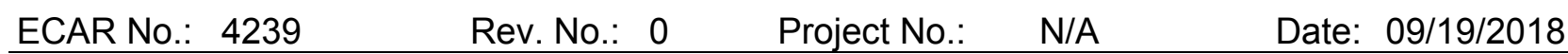

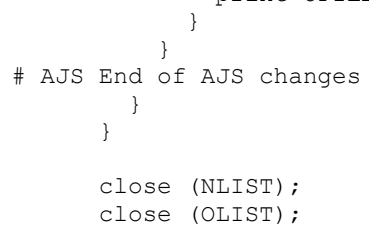

Facility.inp (input file for mkFiles.pl)

$\begin{array}{ll}\text { Facility } & \text { WindFile } \\ \text { MFC } & \text { EBRL6-15.WND }\end{array}$

NucList.inp (input file for mkFiles.pl)

$$
\begin{aligned}
& \mathrm{Al}-28 \\
& \mathrm{C}-14 \\
& \mathrm{C}-58 \\
& \mathrm{C}-60 \\
& \mathrm{Cr}-51 \\
& \mathrm{Cu}-64 \\
& \mathrm{Cu}-66 \\
& \mathrm{~F}-55 \\
& \mathrm{Fe}-59 \\
& \mathrm{H}-3 \\
& \mathrm{Mn}-54 \\
& \mathrm{Mo}-93 \\
& \mathrm{Mo}-93 \mathrm{~m} \\
& \mathrm{Mo}-99 \\
& \mathrm{Nb}-92 \\
& \mathrm{Nb}-94 \\
& \mathrm{Nb}-95 \\
& \mathrm{Nb}-95 \mathrm{~m} \\
& \mathrm{Nb}-96 \\
& \mathrm{Nb}-97 \\
& \mathrm{Ni}-59 \\
& \mathrm{Ni}-63 \\
& \mathrm{Ni}-66 \\
& \mathrm{P}-32 \\
& \mathrm{P}-33 \\
& \mathrm{Ru}-103 \\
& \mathrm{~S}-35 \\
& \mathrm{Sc}-47 \\
& \mathrm{~S}-48 \\
& \mathrm{~T}-99 \\
& \mathrm{Y}-89 \mathrm{~m} \\
& \mathrm{Y}-90 \\
& \mathrm{Zn}-65 \\
& \mathrm{Zr}-89 \\
& \mathrm{Zr}-95 \\
& \mathrm{Z} r-97 \\
&
\end{aligned}
$$

\section{RunFiles.pl}

\# RunFiles.pl

\# This script runs all the CAP88 files in a given directory

$\#==================+==1$
$\#$ REQUIRED USER INPUT

\# --- Path to the input files (excluding specific facility name)

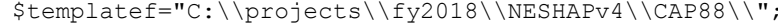
\$wrkdir="C: $\backslash \backslash$ projects $\backslash \backslash$ fy2018 $\backslash \backslash$ NESHAPv $4 \backslash \backslash$ CAP88 $\backslash \backslash$ Scripts"; 
TEM-10200-1

$12 / 19 / 17$

Rev. 08

ENGINEERING CALCULATIONS AND ANALYSIS Page C7 of C10

Estimation of dose from potential radionuclide emissions from the Sample Preparation

Title: $\quad$ Laboratory at the Materials and Fuels Complex

$\begin{array}{lllll}\text { ECAR No.: } 4239 & \text { Rev. No.: } & 0 & \text { Project No.: N/A } & \text { Date: } 09 / 19 / 2018\end{array}$

\# --- File containing all the facility names - These names correspond to directories for each calcilites

\$FacAndWnd = "Facility.inp"; \# facility and wind file names

\# --- Path to the wind files

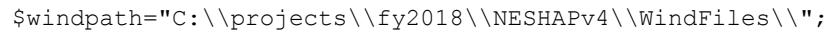

\# --- Facility name and wind file format

$\begin{array}{lll}\# & \text { Facility } & \text { WindFile header (discarded) } \\ \# & \text { CFA } & \text { 690L08. WND } \\ \# & \text { CITRC } & \text { PBL08. WND } \\ \# & \text { INTEC-ICDF } & \text { GRIL8. WND } \\ \# & \cdot & \\ \# & \cdot\end{array}$

\# Get list of facilities

open (INFILE, "<\$FacAndWnd") ;

\$line=<INFILE $>$;

\$nfac=0;

\# read and discard header

while (\$line $=<$ INFILE $>$ )

afield = split /[ $\backslash t]+/$, \$line; \# split field

\$facID [\$nfac] =\$field[0];

\$wndfile [\$nfac]=\$field [1];

\}

nfac $=\$ n f a c+1$

close (INFILE);

\# get list of nuclides

open (INFILE, "<\$NuclideFile") ;

$\$$ nnuc $=0$;

while (\$line=<INFILE $>$ )

Sline $=\sim \mathrm{s} / \wedge[$ ] $+/ /$;

\# delete initial spaces

chop (\$line);

\# remove carrige return

dfield = split $/[\backslash t]+/$, Sline;

\$nucfiles $[\$$ nnuc] $=\$$ field $[0]$;

$\$$ nnuc $=\$$ nnuc +1

close (INFILE);

\# Loop through each facility, write a batch file to run CAP88, and run batch file

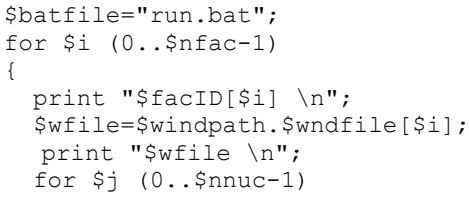


TEM-10200-1

$12 / 19 / 17$

Rev. 08

ENGINEERING CALCULATIONS AND ANALYSIS Page C8 of C10

Estimation of dose from potential radionuclide emissions from the Sample Preparation

Title: $\quad$ Laboratory at the Materials and Fuels Complex

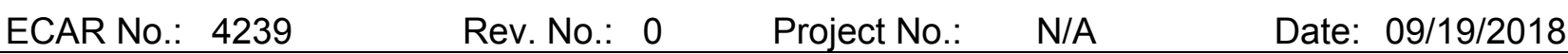

\section{getCAP88dose2.pl}

\# getCAP88dose.pl

\# This script extracts doses from the CAP88 *. SUM file and writes it to a text file

\# The file contaning list of output files (\$filein) is generated in the script mkfiles.pl

\# $================$
\# REQUIRED USER INPUT

\# Working Directory

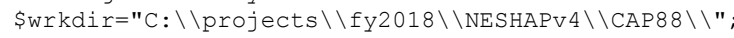

\# File contaning list of output files

\$filein="OutputFiles.inp";

\# --- File containing all the facility names - These names correspond to directories for each facilites \$FacAndWnd = "Facility.inp"; \# facility and wind file names

\# --- Output File

\$fileout="tempdoses.txt";

\# --- Number of MEI locations

\$nmei=62;

\#--- MEI File

\$meifile="MEI.dat".

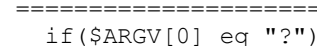

\{

print "usage getCAP88dose.pl [file name containing files to process] [output file] [facility name] \n"; \} die;

Sfilein=\$ARGV[0] :

\$fileout $=\$$ ARGV $[1]$;

\$facility_name=\$ARGV[2];

print "\$filein \n";

\# Open and store file containing list of output files and make nuclide names

open (INFILE, "<\$filein")

$\$ n f=0 ;$

while (\$line=<INFILE $>$ )

\{

\$line $=\sim \mathrm{s} / \wedge[$ ] $/ /$; \# delete initial spaces

chop (\$line); \# remove carrige return

afield = split / [ \t]+/, \$line; \#split field

\$files[\$nf]=\$field[0];

\$nname $[\$ \mathrm{nf}]=\$ \mathrm{field}[1]$;

\# $\quad$ \$nname $[\$ \mathrm{nf}]=\operatorname{substr}(\$ \mathrm{files}[\$ \mathrm{nf}], 0,-5)$;

$\$ n f=\$ n f+1$

close (INFILE);

$\$ n f=\$ n f-1$;

\# Open and store file containing list of facilities

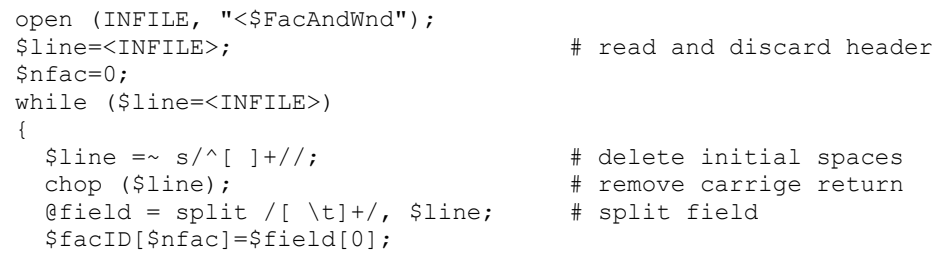

\# read and discard header

\# delete initial spaces

\# remove carrige return

\# split field 
TEM-10200-1

Rev. 08

\section{ENGINEERING CALCULATIONS AND ANALYSIS Page C9 of C10}

Estimation of dose from potential radionuclide emissions from the Sample Preparation

Title: $\quad$ Laboratory at the Materials and Fuels Complex

$\begin{array}{llllll}\text { ECAR No.: } 4239 & \text { Rev. No.: } & 0 & \text { Project No.: } & \text { N/A } & \text { Date: 09/19/2018 }\end{array}$

Close (INFILE);

$\$$ nfac $=\$ n f a c-1 ;$

\# load MEI locations

open (INFILE, "<\$meifile");

Sline $=\langle$ INFILE $>$ :

\# read and discard header

\# --- There are 62 MEI locations per facility - so for each faility, store each location

$\$ i=1$;

while (\$line=<INFILE $>$ )

\$line $=\sim \mathrm{s} / \wedge[\mathrm{H}]+/ /$; \# delete initial spaces

chop (\$line); \# remove carrige return

efield = split / $[t]+/$, \$line; \#split field

\$mei_dir $\{\$$ field $[0]\}\{\$ i\}=\$ f i e l d[1]$;

$\$$ mei dist $\{\$ f i e l d[0]\}\{\$ i\}=\$ f i e l d[2]$;

$\$ i=\$ \bar{i}+1 ;$

if $(\$ i>\$$ nmei) $\{\$ i=1$;

close (INFILE);

\# Open output file

open (OUTFILE, ">\$fileout")

print " Number of Files: $\$ n f \backslash n "$;

print " Number of Facilities: \$nfac \n";

print " Number of MEI Locations: \$nmei \n";

$\$ \mathrm{n} 1=0 ;$

$\$ \mathrm{n} 2=1 ;$

for $\$ j(0 \ldots$ nfac $)$

print "[\$j] \n";

print "Facility: \$facID[\$j] \n";

$\$ \mathrm{cnt}=0$;

for $\$ i(0 \ldots$ i $f)$

\{

if ( $\$$ i $5==0$ ) \{ print STDERR "\$i"; \}

else \{ print STDERR ".";

\$filein=\$wrkdir.\$facID[\$j]." \\".\$files[\$i];

open (INFILE, "<\$filein");

while $(\$$ line $=<$ INFILE $>)$

\{

if (\$line= /INDIVIDUAL LIFETIME RISK/)

\{last;

if $(\$$ line $=\sim /$ Distance $/)$

a field $=(-1,-1,-1,-1,-1,-1,-1,-1)$

\$line=<INFILE $>$; \# skip 2 lines

\# get distances

\$line $=<$ INFILE $>$

\$line=<INFILE $>$;

\$line $=\sim s / \wedge[$ ]+//; \# delete initial spaces

chop (\$line); \# remove carrige return

efield = split / [ \t]+/, \$line; \#split field

\# find number of values

$\$$ nvals=0;

for $\$ k(1 \ldots 7)$

l

if $(\$ f i e l d[\$ k]>0)$ 
TEM-10200-1

$12 / 19 / 17$

Rev. 08

\section{ENGINEERING CALCULATIONS AND ANALYSIS Page C10 of C10}

Estimation of dose from potential radionuclide emissions from the Sample Preparation

Title: $\quad$ Laboratory at the Materials and Fuels Complex

$\begin{array}{llllll}\text { ECAR No.: } 4239 & \text { Rev. No.: } & 0 & \text { Project No.: } & \text { N/A } & \text { Date: 09/19/2018 }\end{array}$

\# get dose values

\$nvals $=\$$ nvals 1 ;

\$dist $[\$$ nvals $]=\$ f i e l d[\$ k]$

\$line=<INFILE $>$; \# skip 2 lines

\$line=<INFILE $>$;

for $\$ \mathrm{k}(1 \ldots 16)$

\$line $=<$ INFILE $>$

Sline $=\sim \mathrm{s} / \wedge[]+/ /$; \# delete initial spaces

chop (\$line); \# remove carrige return

afield = split /[ \t]+/, \$line; \#split field

$\$$ direct $=\$$ field $[\$ 0]$

for $\$ \mathrm{~m}(1 \ldots$ nvals $)$

\# --- Loop through all MEIs to the facility. if the location is an MEI and print it.

for $\$ k k$ (1..\$nmei)

\{

if $(\$ \operatorname{dist}[\$ m]==\$ \operatorname{mei} \operatorname{dist}\{\$ f a c I D[\$ j]\}\{\$ \mathrm{kk}\}$ \&\& $\$ \operatorname{direct}$ eq $\$ \operatorname{mei} \operatorname{dir}\{\$ f a c I D[\$ j]\}\{\$ \mathrm{kk}\})$

print OUTFILE

"\$facID $[\$ j]$, \$nname [\$i], \$mei_dir $\{\$ f a c I D[\$ j]\}\{\$ k k\}, \$ m e i \_d i s t\{\$ f a c I D[\$ j]\}\{\$ k k\}, \$ f i e l d[\$ m] \backslash n " ;$

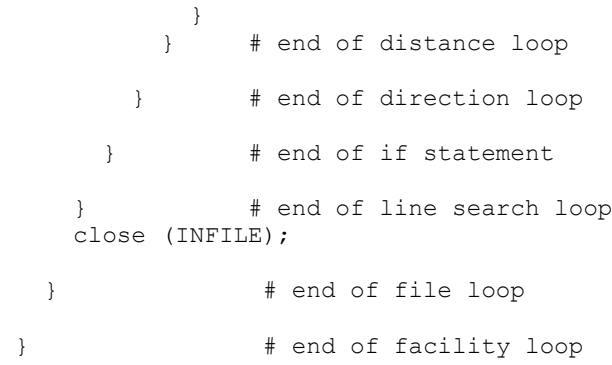

\# Close output file and terminate

close OUTFILE; 